\title{
PRENYLATED FLAVONOIDS FROM Maclura tinctoria FRUITS
}

\author{
Sayuri de Oliveira Oyama e Luiz Antonio de Souza \\ Departamento de Biologia, Universidade Estadual de Maringá, 87025-500 Maringá-PR, Brasil \\ Debora Cristina Baldoqui e Maria Helena Sarragiotto \\ Departamento de Química, Universidade Estadual de Maringá, 87025-500 Maringá-PR, Brasil \\ Adriano Antônio Silva* \\ Departamento de Ciências da Natureza, Universidade Federal do Acre, 69915-900 Rio Branco-AC, Brasil
}

Recebido em 13/8/12; aceito em 4/2/13; publicado na web em 24/5/13

\begin{abstract}
A phytochemical investigation of Maclura tinctoria fruits yielded five flavonoids, including one prenylated flavonol (licoflavonol) and four prenylated isoflavones (wighteone, derrone, alpinum isoflavone, and 6-(2,2-dimethyl-2H-chromen-6-yl)-2-(1-hydroxy1-methylethyl)-2,3-dihydro-5H-furo[3,2-g]chromen-5-one). The structures of the isolates were established by analyzing their spectroscopic data. Compound 6-(2,2-dimethyl-2H-chromen-6-yl)-2-(1-hydroxy-1-methylethyl)-2,3-dihydro-5H-furo[3,2-g]chromen5 -one is new and the other isolates are described for the first time in this species.
\end{abstract}

Keywords: Moraceae; Maclura tinctoria; prenylated flavonoids.

\section{INTRODUCTION}

Maclura tinctoria (L.) D. Don ex Steudel (Chlorophora tinctoria Gaud.) according to Barroso, ${ }^{1}$ popularly known as "amoreira," "amora-do-mato" or "taíuva," is a tree having a height of 10-20 $\mathrm{m}$ and a diameter of $40-60 \mathrm{~cm}$, belonging to the family Moraceae and growing in humid and dry tropical forests of Central and South America. ${ }^{1,2}$ Its wood has been used in carpentry, furniture manufacturing, and civil construction, as well as for extraction of morin, a yellowish pigment employed for spot testing of certain metal ions. ${ }^{3,4}$ $M$. tinctoria bark infusions have been reported to be used against toothache by the Kaiowá and Guarani indigenous populations living in the Caarapó Reserve in Mato Grosso do Sul state, Brazil. ${ }^{5}$ The resin of the plant is used for the same purpose in the Amazonian indigenous community of Porvenir, Bajo Paragua Indian Reservation, Bolivia. ${ }^{6}$ The species also furnishes diuretic and anti-venereal agents and is used in Latin America to treat urinary infections, cough, gout, pharyngitis, rheumatism, sore throat, and syphilis.?

Chemical studies of the Maclura genus have revealed prenylated flavonoids as main constituents. In M. pomifera, the most studied species of the genus, several flavonoids have been described, including isoflavones from the fruits, root, bark, and heartwood of the plant. ${ }^{8-13}$ Five prenylated flavones and three prenylated isoflavones have been isolated from chloroform extracts of stems and leaves. ${ }^{11}$

$M$. tinctoria is relatively well studied from a phytochemical viewpoint; however, the studies reported have used only the bark and leaves of the plant. Five prenylated flavonoids, four prenylated chalcones and one diprenylisoflavone, were isolated from an ethanol extract of $M$. tinctoria leaves and identified as $2 ', 4^{\prime}, 4,2^{\prime}$-tetrahydroxy-3'(3'-methylbut-3'-enyl)-chalcone, isobavachalcone, bakuchalcone, bavachromanol, and 5,7,3:4'-tetrahydroxy-6,8-diprenylisoflavone (6,8-diprenylorobol). ${ }^{14}$ Bioassay-guided fractionation of the bark extract by tracking of HIV-inhibitory activity afforded seven prenylated phenolic derivatives from the active fractions, including the prenylated xanthones macluraxanthone $\mathrm{B}$, macluraxanthone $\mathrm{C}$, gartanin, and desoxygartanin, along with the prenylated flavones cudraflavone $\mathrm{C}$, dihydrocudraflavone $\mathrm{B}$, and isocyclomulberrin. ${ }^{15}$

*e-mail: aasilva@ufac.br
The flavonoids steppogenin, steppogenin 4'-O- $\beta$-D-glucoside, orobol, orobol 5,3'-di-O-methyl-8-C-glucoside, orobol 7-O- $\beta$-D-glucoside, aromadendrin, and dihydromorin were isolated from the $M$. tinctoria bark extract. ${ }^{16}$ Antioxidant chalcone glycosides and flavanones were also reported from the stem bark of this plant. The isolated compounds were characterized as eriodictyol $7-\mathrm{O}-\alpha-\mathrm{D}$-glucopyranoside, naringenin, naringenin 4 '-O- $\alpha$-D-glucopyranoside, 3'-(3-methyl2-butenyl)-4'-O- $\alpha$-D-glucopyranosyl-4,2'-dihydroxychalcone, 4'-O- $\alpha$-D-(2"-p-coumaroyl)glucopyranosyl-4,2',3'-trihydroxychalcone, 4'-O- $\alpha$-D-(2"-p-coumaroyl-6"-acetyl)glucopyranosyl-4,2',3'trihydroxychalcone, and 4'-O- $\alpha-\mathrm{D}-(2 "$-acetyl-6"-cinnamoyl) glucopyranosyl-4,2',3'-trihydroxychalcone. ${ }^{17}$

In this study, we report the isolation and structural elucidation of a new compound, identified as 6-(2,2-dimethyl-2H-chromen-6-yl)2-(1-hydroxy-1-methylethyl)-2,3-dihydro-5 $\mathrm{H}$-furo[3,2- $g$ ]chromen5 -one), along with four known prenylated flavonoids from the fruits of $M$. tinctoria.

\section{EXPERIMENTAL}

\section{General experimental}

${ }^{1} \mathrm{H}$ and ${ }^{13} \mathrm{C}$ NMR spectra were recorded on a Varian Mercury Plus spectrometer at 300 and $75.5 \mathrm{MHz}$, respectively, using $\left(\mathrm{CD}_{3}\right)_{2} \mathrm{CO}$ as solvent and TMS as reference. High resolution mass spectra were obtained in a LTQ-Orbitrap hybrid mass spectrometer (Thermo Fischer Scientific, Bremen, Germany). EI-MS spectra were recorded on a Thermoelectron Corporation Focus-DSQ II spectrometer at $70 \mathrm{eV}$. Column chromatography (CC) was performed using Sephadex LH20 or silica gel 60 Merck (70-30 mesh ASTM). TLC was performed on precoated silica gel $60 \mathrm{G}$ or $60 \mathrm{GF}_{254}$ Merck. All solvents were redistilled before use.

\section{Plant material}

Fruits of M. tinctoria were collected in December 2008 at the Bosque dos Pinheiros, a remnant forest in an urban area in MaringáPR, Brazil. The plant was identified by Dr. Sergio Romaniuc Neto (Instituto de Botânica, São Paulo, Brazil). A voucher specimen 
has been deposited in the herbarium of the Biology Department, Universidade Estadual de Maringá (HUEM 16499).

\section{Extraction and isolation}

Dried fruits with seeds $(670 \mathrm{~g})$ of $M$. tinctoria were powdered and exhaustively extracted with methanol at room temperature. Vacuum concentration yielded the crude methanol extract (123 g), which was suspended in $\mathrm{MeOH}: \mathrm{H}_{2} \mathrm{O}(1: 1)$ and partitioned into $\mathrm{CH}_{2} \mathrm{Cl}_{2}$, EtOAc, and $\mathrm{BuOH}$. The solvents were evaporated to give $\mathrm{CH}_{2} \mathrm{Cl}_{2}$ (24.7 g), EtOAc (9.60 g), BuOH (32.4 g), and aqueous $(57.1 \mathrm{~g})$ fractions. An aliquot of the $\mathrm{CH}_{2} \mathrm{Cl}_{2}$ fraction $(3 \mathrm{~g})$ was passed through a Sephadex LH-20 chromatographic column using $\mathrm{MeOH}$ as eluent, yielding 18 fractions of $15 \mathrm{~mL}$ each. This procedure was repeated four times, and the fractions were grouped on the basis of TLC similarity (A1 to A15). Fraction A4 (543 mg) was purified using $\mathrm{CC}$ on silica gel with a mixture of $n$-hexane, $\mathrm{CH}_{2} \mathrm{Cl}_{2}$, and EtOAc in increasing polarity as eluent, followed by preparative TLC $\left(\mathrm{CH}_{2} \mathrm{Cl}_{2}\right.$ :EtOAc; $\left.7: 3\right)$ of the subfraction eluted from $\mathrm{CC}$ with $\mathrm{CH}_{2} \mathrm{Cl}_{2}$ :EtOAc (6:4), to yield pure compound $\mathbf{1}(8 \mathrm{mg}$ ). Fraction A9 (376 mg) was subjected to CC on silica gel, using $n$-hexane containing increasing amounts of EtOAc (up to 100\%) as eluent, to give 108 fractions of $20 \mathrm{~mL}$ each (A9.1 to A9.108). Subfraction A9.20 (72 mg) was subjected to preparative TLC with $\mathrm{CH}_{2} \mathrm{Cl}_{2}$ (100\%) elution. The fraction with $R_{f}=0.28$ was dissolved in $\mathrm{CHCl}_{3}$ and subjected to precipitation with hexane. The precipitate $(10 \mathrm{mg})$ was identified as pure compound $\mathbf{2}$, and the supernatant yielded a mixture of compounds $\mathbf{2}$ and $\mathbf{3}$ (12 mg). Fraction A15 (84 mg) was subjected to preparative TLC with hexane: $\mathrm{CH}_{2} \mathrm{Cl}_{2}$ (2:8) elution. The fraction with $R_{f}=0.20$ was subjected to subsequent preparative TLC using hexane: $\mathrm{CH}_{2} \mathrm{Cl}_{2}(2: 8)$ as eluent, to yield pure compounds 4 (9 $\mathrm{mg}$ ) and $\mathbf{5}(11 \mathrm{mg})$.

\section{RESULTS AND DISCUSSION}

Fractionation of the $\mathrm{CH}_{2} \mathrm{Cl}_{2}$ fraction by gel permeation chromatography using a Sephadex LH-20 column, followed by CC on silica gel and preparative TLC of subfractions, afforded five prenylated flavonoids (1-5) (Figure 1). The structures of the isolated compounds were determined by analysis of their spectral data (MS and 1D and 2D NMR).

The new prenylated isoflavone (1), 6-(2,2-dimethyl- $2 \mathrm{H}$ chromen-6-yl)-2-(1-hydroxy-1-methylethyl)-2,3-dihydro-5 $H$ furo[3,2-g]chromen-5-one, was obtained as an amorphous yellow powder. The HR-ESIMS of 1, in the positive-ion mode, exhibited a molecular ion peak $[\mathrm{M}+\mathrm{H}]^{+}$at $\mathrm{m} / z$ 435.1800, consistent with the molecular formula $\mathrm{C}_{26} \mathrm{H}_{26} \mathrm{O}_{6}$. The ${ }^{13} \mathrm{C}$ NMR spectra (Table 1) of compound 1 revealed characteristic signals for C-2, C-3, and C-4 of an isoflavone at $\delta 151.5,122.7$, and 175.1 , respectively. The additional signals for twelve aromatic carbons, eight non-hydrogenated, and four methine $\mathrm{sp}^{2}$-carbons, evidenced an isoflavone skeleton with di- and tri-substituted aromatic rings. This was confirmed by the signals of one aromatic hydrogen as singlet at 6.49 (s, H-8) and of the coupled aromatic hydrogens at $\delta 7.19(\mathrm{~d}, J=2.1 \mathrm{~Hz}$, H-2'), 6.72 (d, $J=8.4 \mathrm{~Hz}, \mathrm{H}-5^{\prime}$ ) and $\delta 7.25$ (dd, $J=8.4$ and 2.1 $\mathrm{Hz}, \mathrm{H}-6$ '), in the ${ }^{1} \mathrm{H}$ NMR spectra. The signals at $\delta 3.29(\mathrm{~m}, 2 \mathrm{H}$, H-3"') and $\delta 4.74$ (t, $J=7.20 \mathrm{~Hz}, 1 \mathrm{H}, \mathrm{H}-2$ '"') and of two methyl groups at $\delta 1.24(\mathrm{~s}, 3 \mathrm{H})$ and $\delta 1.21(\mathrm{~s}, 3 \mathrm{H})$ evidenced the presence of the 2-(1-hydroxy-1-methylethyl)-2,3-dihydrofuran system, which was confirmed by the corresponding ${ }^{13} \mathrm{C}$ NMR signals at $\delta 28.0(\mathrm{C}$ 3'"), 92.0 (C-2"'), and $\delta 71.4$ (C-4"'). The linkage of this group at C-6 and C-7 of ring A was established by the correlation between H-3" " $(\delta$ 3.29) and C-6 ( $\delta$ 118.4) in the HMBC experiment (Table

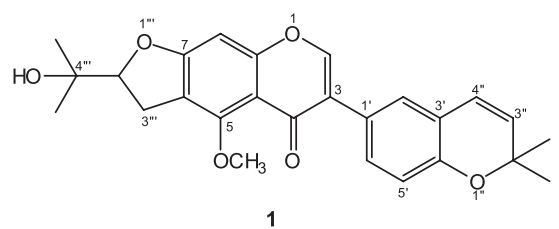<smiles>CC1(C)C=Cc2c(cc(O)c3c(=O)c(-c4ccc(O)cc4)coc23)O1</smiles>

2<smiles>CC1(C)C=Cc2c(cc3occ(-c4ccc(O)cc4)c(=O)c3c2O)O1</smiles><smiles>CC(C)/C=C/c1c(O)cc2occ(-c3ccc(O)cc3)c(=O)c2c1O</smiles><smiles>CC(C)/C=C/c1c(O)cc2oc(-c3ccc(O)cc3)c(O)c(=O)c2c1O</smiles>

Figure 1. Prenylated flavonoids isolated from the fruits of Maclura tinctoria

1). In addition, the ${ }^{1} \mathrm{H}$ and ${ }^{13} \mathrm{C}$ NMR spectra indicated the presence of a dimethylchromene system at $\delta 7.19(\mathrm{~d}, 2.1 \mathrm{~Hz}, \mathrm{H}-2$ '), $6.72(\mathrm{~d}$, 8.4 Hz, H-5'), 7.25 (dd, 8.4 Hz and $2.1 \mathrm{~Hz}, \mathrm{H}-6$ '), 6.37 (d, $9.9 \mathrm{~Hz}$, H-4"), and 5.68 (d, $9.9 \mathrm{~Hz}, \mathrm{H}-5$ ").

The assignment of all signals observed in ${ }^{1} \mathrm{H}$ and ${ }^{13} \mathrm{C}$ NMR spectra of 1 was corroborated by HMQC and HMBC experiments (Table 1). These data revealed that $\mathbf{1}$ is closely related to ulexin D, isolated from Ulex airensis, ${ }^{18}$ differing by the presence of a $5-\mathrm{OCH}_{3}$ instead of a 5-OH group in ulexin D. The linkage of the methoxyl group $\left(\delta_{\mathrm{H}} 3.87, \mathrm{~s}, 3 \mathrm{H}\right)$ at $\mathrm{C}-5$ was confirmed by the downfield (approximately 6-9 ppm) shift observed for $\mathrm{C}-6$ and $\mathrm{C}-10$ of compound 1 owing to the methylation effect, compared with the corresponding carbons of ulexin $\mathrm{D}$. This evidence was also corroborated by the carbonyl signal at $\delta 175.1$ in the ${ }^{13} \mathrm{C}$ NMR spectrum of $\mathbf{1}$, instead of at $\delta 181.7$ as seen in ulexin $\mathrm{D}$, in agreement with the lack of a free 5-OH group.

The known prenylated isoflavones derrone (2), ${ }^{19}$ alpinum isoflavone (3), ${ }^{19,20}$ and wighteone (4), ${ }^{18}$ were identified by comparing their NMR data with those reported in the literature. Derrone (2) and alpinum isoflavone (3) are isomers, possessing isoprenyl groups linked at C-8 and C-6, respectively. In the ${ }^{1} \mathrm{H}$ and ${ }^{13} \mathrm{C}$ NMR spectra of derrone (2), the H-6 and C-6 appears at $\delta 6.19$ (s, 1H) and $\delta$ 101.9, respectively, whereas in alpinum isoflavone (3) the signals for $\mathrm{H}-8$ and $\mathrm{C}-8$ are observed at $\delta 6.36(\mathrm{~s}, 1 \mathrm{H})$ and $\delta 95.5$, respectively.

Derrone (2) and alpinum isoflavone (3) along with other prenylated isoflavones have been isolated from Ficus nymphaefolia, a species of Moraceae. ${ }^{21}$ Wighteone (4) was previously isolated from M. pomifera leaves ${ }^{11}$ and Erythrina indica stem bark. Its potential cytotoxicity to human $\mathrm{KB}$ cells has also been reported. ${ }^{22}$

The prenylated flavonol 5 was first isolated from Glycyrrhiza glabra roots $^{23}$ and identified as licoflavonol by comparing its data with those previously reported. ${ }^{23,24}$ 
Table 1. ${ }^{1} \mathrm{H}$ and ${ }^{13} \mathrm{C}$ NMR data of compound $\mathbf{1}$ in $\left(\mathrm{CD}_{3}\right)_{2} \mathrm{CO}$

\begin{tabular}{|c|c|c|c|}
\hline Position & ${ }^{13} \mathrm{C}$ & $\begin{array}{c}{ }^{1} \mathrm{H} \text { (mult., integ., } \\
J \text { in } \mathrm{Hz})\end{array}$ & $\begin{array}{c}\mathrm{HMBC} \\
\mathrm{H} \rightarrow \mathrm{C}\end{array}$ \\
\hline \multicolumn{4}{|l|}{1} \\
\hline 2 & 151.5 & $7.95(\mathrm{~s}, 1 \mathrm{H})$ & $4,9,1^{\prime}$ \\
\hline 3 & 122.7 & & - \\
\hline 4 & 175.1 & & - \\
\hline 5 & 156.7 & & - \\
\hline 6 & 118.4 & & - \\
\hline 7 & 165.6 & & - \\
\hline 8 & 93.9 & $6.49(\mathrm{~s}, 1 \mathrm{H})$ & $6,7,9,10$ \\
\hline 9 & 160.0 & & - \\
\hline 10 & 113.0 & & - \\
\hline 1 & 125.5 & & - \\
\hline 2 & 127.9 & $7.19(\mathrm{~d}, 1 \mathrm{H}, 2.1)$ & $3,4^{\prime}, 6^{\prime}$ \\
\hline 3 & 121.6 & - & - \\
\hline 4 ' & 153.3 & - & - \\
\hline 5 & 116.4 & $6.72(\mathrm{~d}, 1 \mathrm{H}, 8.4)$ & $1 ’$ \\
\hline 6 & 130.5 & $\begin{array}{c}7.25(\mathrm{dd}, 1 \mathrm{H}, 8.4 \text {; } \\
2.1)\end{array}$ & $2^{\prime}, 4^{\prime}$ \\
\hline $2 "$ & 76.9 & - & - \\
\hline $3 "$ & 131.6 & $5.68(\mathrm{~d}, 1 \mathrm{H}, 9.9)$ & 3,2 ', \\
\hline $4 "$ & 125.5 & $6.37(\mathrm{~d}, 1 \mathrm{H}, 9.9)$ & $4^{\prime}, 2$ '” \\
\hline $\mathrm{CH}_{3}-2 "$ & 28.1 & $1.40(\mathrm{~s}, 6 \mathrm{H})$ & $2 ", 3 ”$ \\
\hline $2, "$ & 92.0 & $4.74(\mathrm{t}, 1 \mathrm{H}, 7.2)$ & - \\
\hline 3, & 28.0 & $3.29(\mathrm{~m}, 2 \mathrm{H})$ & 6 \\
\hline $4, "$ & 71.4 & - & - \\
\hline $\mathrm{CH}_{3} \mathrm{a}-4, "$ & 25.1 & $1.24(\mathrm{~s}, 3 \mathrm{H})$ & $\mathrm{CH}_{3} \mathrm{~b}-4 ",, 4 "$, \\
\hline $\mathrm{CH}_{3} \mathrm{~b}-4, "$ & 25.8 & $1.21(\mathrm{~s}, 3 \mathrm{H})$ & $\mathrm{CH}_{3} \mathrm{a}-4, ", 2 ",, 4 "$, \\
\hline $\mathrm{OCH}_{3}$ & 60.8 & $3.87(\mathrm{~s}, 3 \mathrm{H})$ & 5 \\
\hline
\end{tabular}

\section{CONCLUSION}

Excepting wighetone (4), all isolated compounds are being described for the first time from Maclura genus. However, several prenylated isoflavones have been reported to occur in $M$. pomifera p $^{8-12}$ and other species of the Moraceae family. ${ }^{21,25,26}$ The isolation of prenylated isoflavones from $M$. tinctoria may contribute to further chemotaxonomic studies on the genus Maclura and family Moraceae.

\section{SUPPLEMENTARY MATERIAL}

The RMN and mass spectra for compounds $\mathbf{1 - 5}$ are available at http://quimicanova.sbq.org.br as a free-access PDF file.

\section{ACKNOWLEDGMENTS}

The authors are grateful to CAPES and CNPq for fellowships (SOO and AAS), to Dr. A. J. Marsaioli (UNICAMP) for HRMS spectra, and to Fundação Araucária (Paraná State, Brazil) for financial support.

\section{REFERENCES}

1. Barroso, G. M.; Morrim, M. P.; Peixoto, A. L.; Ichaso, C. L. F.; Frutos e Sementes. Morfologia Aplicada à Sistemática de Dicotiledôneas, $1^{\mathrm{st}}$ ed., UFV: Viçosa, 1999.

2. Carvalho, P. E. R.; Espécies Arbóreas Brasileiras (Volume 1), $1^{\text {st }}$ ed., Embrapa: Distrito Federal, 2003.

3. Paula, J. E.; Alves, J. H. L.; Madeiras Nativas - Anatomia, Dendrologia, Dendrometria, Produção e Uso, $1^{\text {st }}$ ed., Cinco continentes: Brasília, 1997.

4. Wu, T. W.; Zeng, L. H.; Wu, J.; Fung, K. P.; Biochem. Pharmacol. 1994, 47, 1099.

5. Bueno, N. R.; Castilho, R. O.; Costa, R. B.; Pott, A.; Pott, V. J.; Scheidt, G. N.; Batista, M. S.; Acta Bot. Bras. 2005, 19, 39.

6. Hajdu, Z.; Hohmann, J.; J. Ethnopharmacol. 2012, 139, 838.

7. http://www.ars-grin.gov/duke/syllabus/module8.htm, accessed November 2012 .

8. Kupeli, E.; Orhan, I.; Toker, G.; Yesilada, E.; J. Ethnopharmacol. 2006, 107, 169.

9. Tian, L.; Blount, J. W.; Dixo, R. A.; FEBS Letters 2006, 580, 6915.

10. Tsao, R.; Yang, R.; Young, J. C.; J. Agric. Food Chem. 2003, 51, 6445.

11. Lee, S.; Wood, A. R.; Maier, C. G.; Dixon, R. A.; Mabry, T. J.; Phytochemistry 1998, 49, 2573.

12. Delle Monache, G.; Scurria, R.; Vitali, A.; Botta, B.; Monacelli, B.; Pasqua, G.; Palocci, C.; Cernia, E.; Phytochemistry 1994, 37, 893.

13. Geber, N. N.; Phytochemistry 1986, 25, 1697.

14. ElSohly, H. N.; Joshi, A. S.; Ninrod, A. C.; Walker, L. A.; Clark, A. M.; Planta Medica 2001, 67, 87.

15. Groweiss, A.; Cardellina, J. H.; Boyd, M. R.; J. Nat. Prod. 2000, 63, 1537.

16. ElSohly, H. N.; Joshi, A. S.; Li, X. C.; Ross, S. A.; Phytochemistry 1999, $52,141$.

17. Cioffi, G.; Escobar, L. M.; Braca, A.; Tommasi, N.; J. Nat. Prod. 2003, 66, 1061 .

18. Inghan, J. L.; Keen, N. T.; Hymowitz, T.; Phytochemistry 1977, 16, 1943.

19. Máximo, P.; Lourenço, A.; Feio, S. S.; Roseiro, J. C.; Z. Naturforsch. 2002, 57, 609 .

20. Oh, W. K.; Lee, H. S.; Ahn, S. C.; Ahn, J. S.; Mbafor, J. T.; Wandji, J.; Fomum, Z. T.; Chang, H. K.; Kim, Y. H.; Phytochemistry 1999, 51, 1147.

21. Darbour, N.; Bayet, C.; Rodin-Bercion, S.; Elkhomsi, Z.; Lurel, F.; Chaboud, A.; Guilet, D.; Nat. Prod. Res. 2007, 21, 461.

22. Nkengfack, A. E.; Azebaze, A. G. B.; Waffo, A. K.; Fomum, Z. T.; Meyer, M.; van Heerden, F. R.; Phytochemistry 2001, 58, 1113.

23. Saitoh, T.; Kinoshita, T.; Shibata,S.; Chem. Pharm. Bull. 1976, 24, 1242.

24. Montoro, P.; Maldini, M.; Russo, M.; Postorino, S.; Piacente, S.; Pizza, C.; J. Pharm. Biomed. Anal. 2011, 54, 535.

25. Han, X. H.; Hong, S. S.; Jin, Q.; Li, D.; Kim, H.; Lee, J.; Kwon, S. H.; Lee, D.; Lee, C.; Lee, M. K.; Hwang, B. Y.; J. Nat. Prod. 2009, 72, 164.

26. Darbour, N.; Bayet, C.; Rodin-Bercion, S.; Elkhomsi, Z.; Lurel, F.; Chaboud, A.; Guilet, D.; Nat. Prod. Res. 2007, 21, 461. 


\section{PRENYLATED FLAVONOIDS FROM Maclura tinctoria FRUITS}

\section{Sayuri de Oliveira Oyama e Luiz Antonio de Souza}

Departamento de Biologia, Universidade Estadual de Maringá, 87025-500 Maringá-PR, Brasil

Debora Cristina Baldoqui e Maria Helena Sarragiotto

Departamento de Química, Universidade Estadual de Maringá, 87025-500 Maringá-PR, Brasil Adriano Antônio Silva*

Departamento de Ciências da Natureza, Universidade Federal do Acre, 69915-900 Rio Branco-AC, Brasil

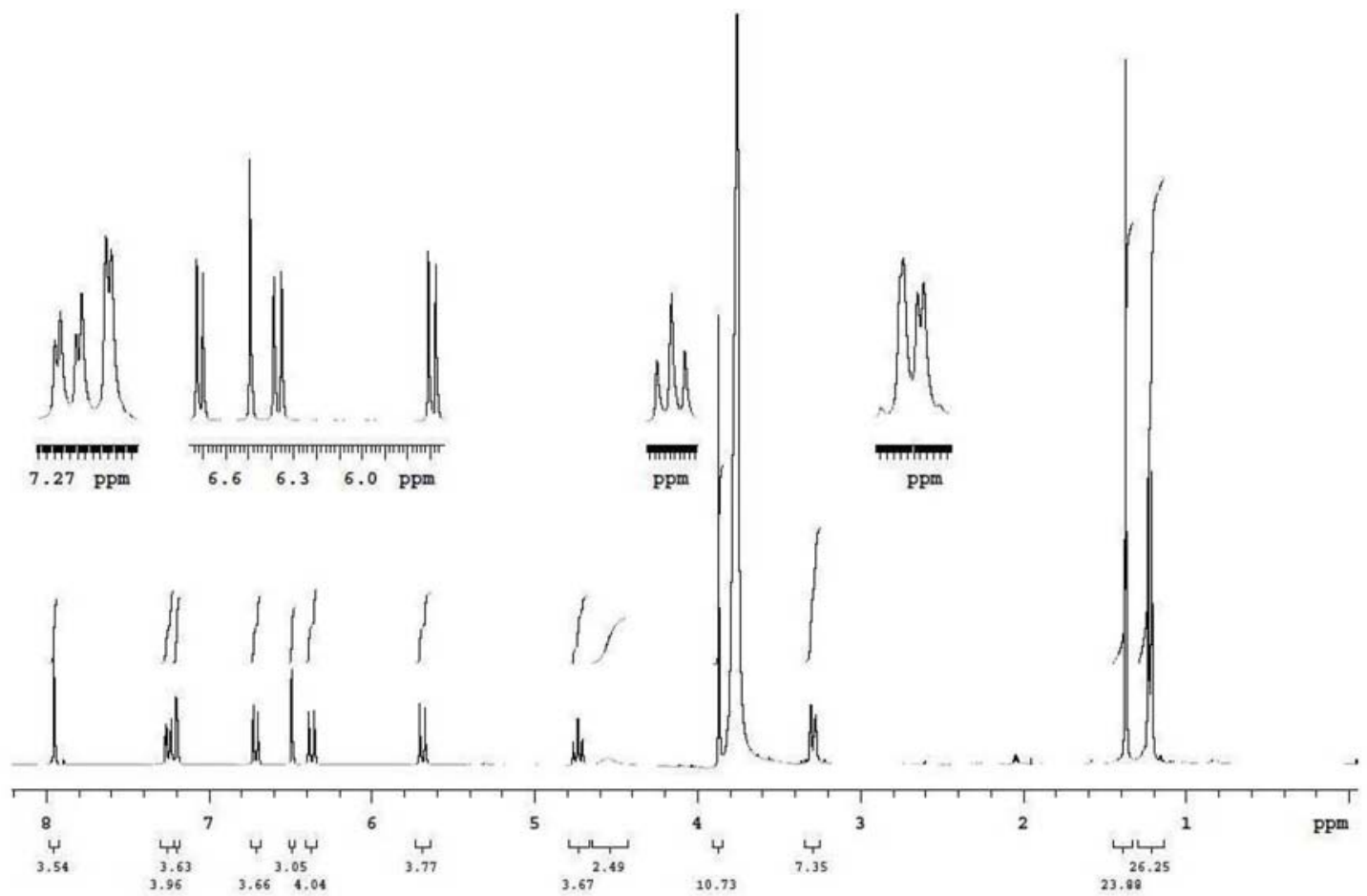

Figure 1S. ${ }^{1} \mathrm{H}$ NMR spectrum $\left(300 \mathrm{MHz},\left(\mathrm{CD}_{3}\right)_{2} \mathrm{CO}\right)$ of coumpond 1 

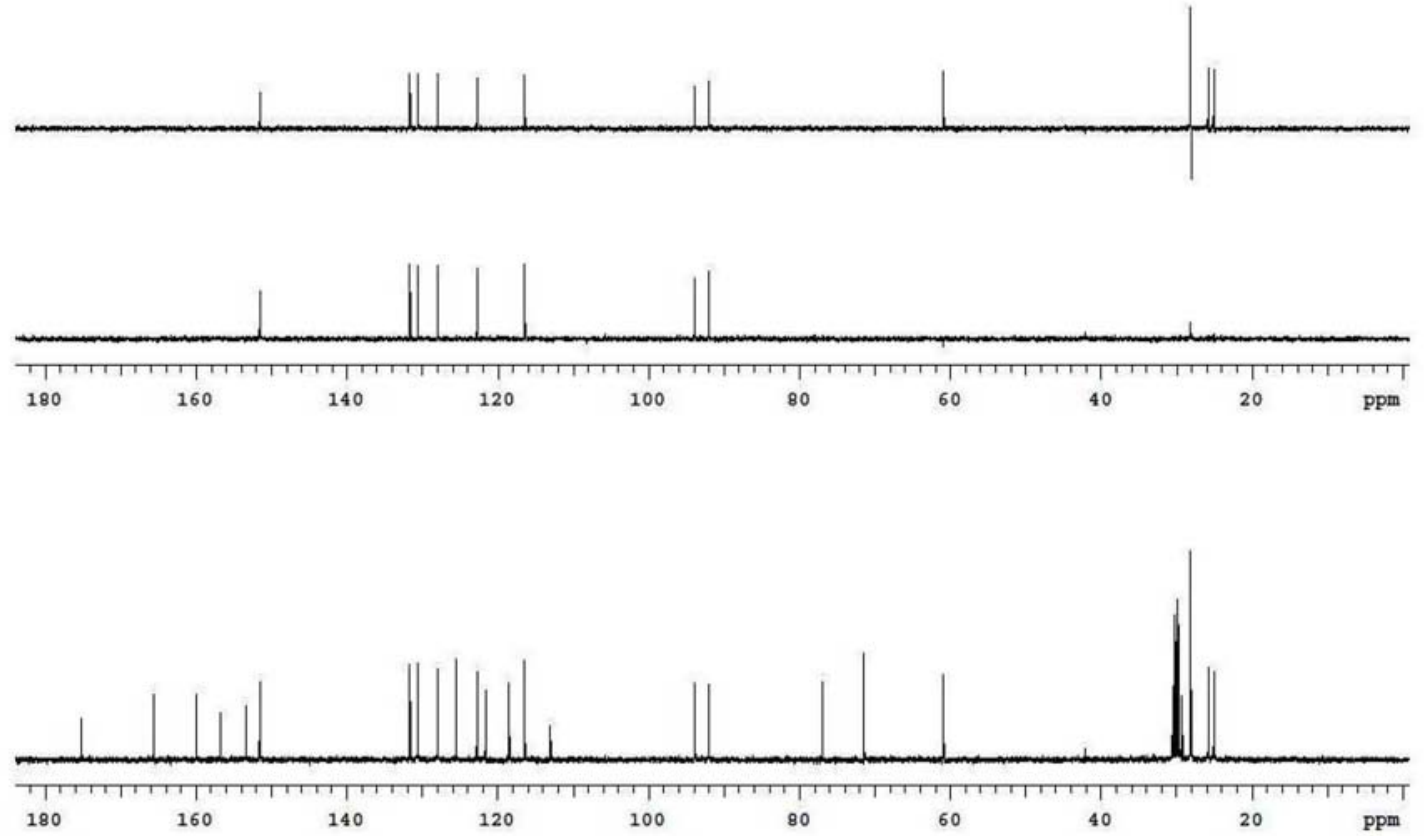

Figure $2 \mathrm{~S} .{ }^{13} \mathrm{C}$ and DEPT 90 spectrum $\left(75 \mathrm{MHz},\left(\mathrm{CD}_{3}\right)_{2} \mathrm{CO}\right)$ of coumpond 1

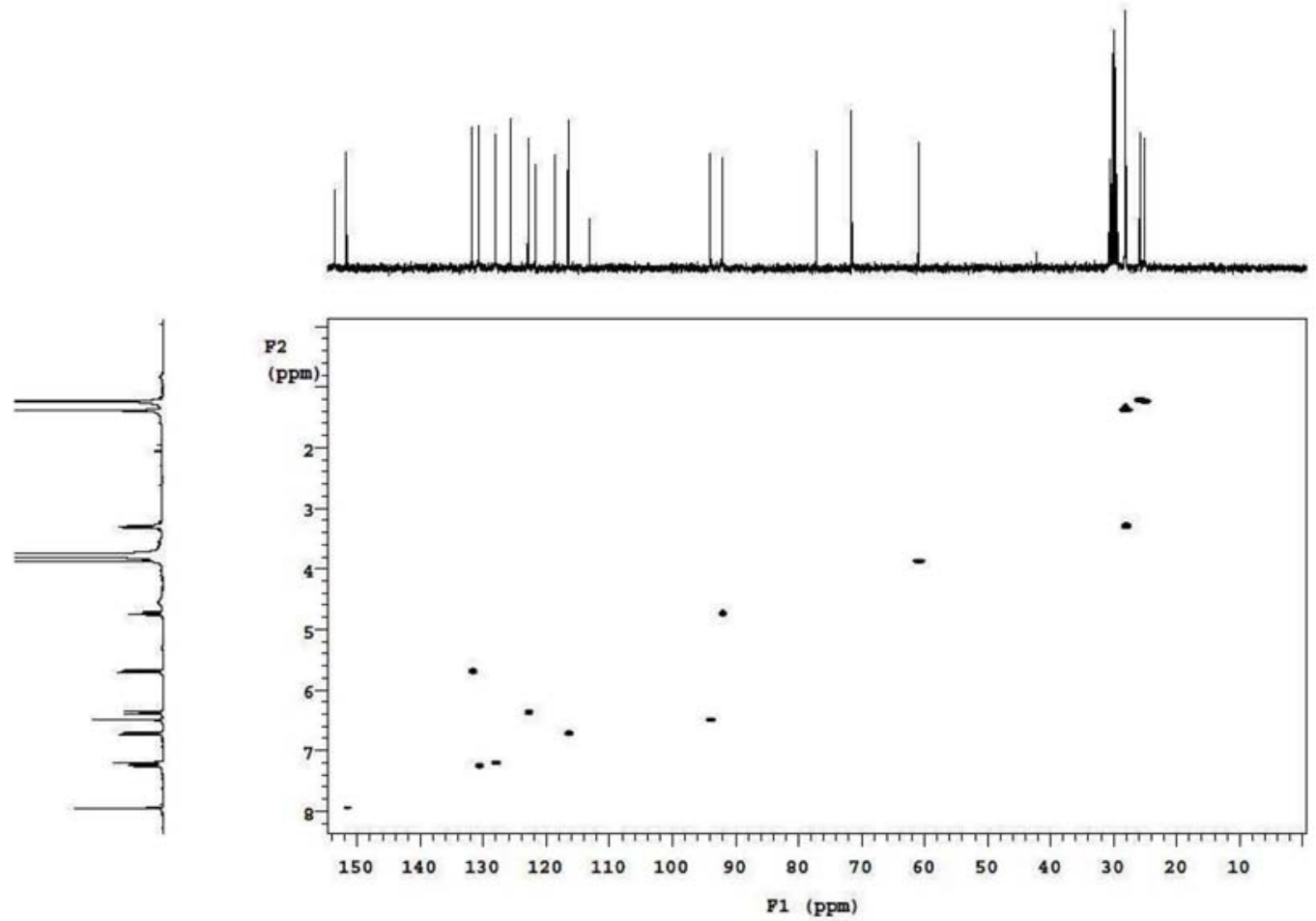

Figure 3S. HSQC spectrum $\left(300 / 75 \mathrm{MHz},\left(\mathrm{CD}_{3}\right)_{2} \mathrm{CO}\right)$ of coumpond 1 


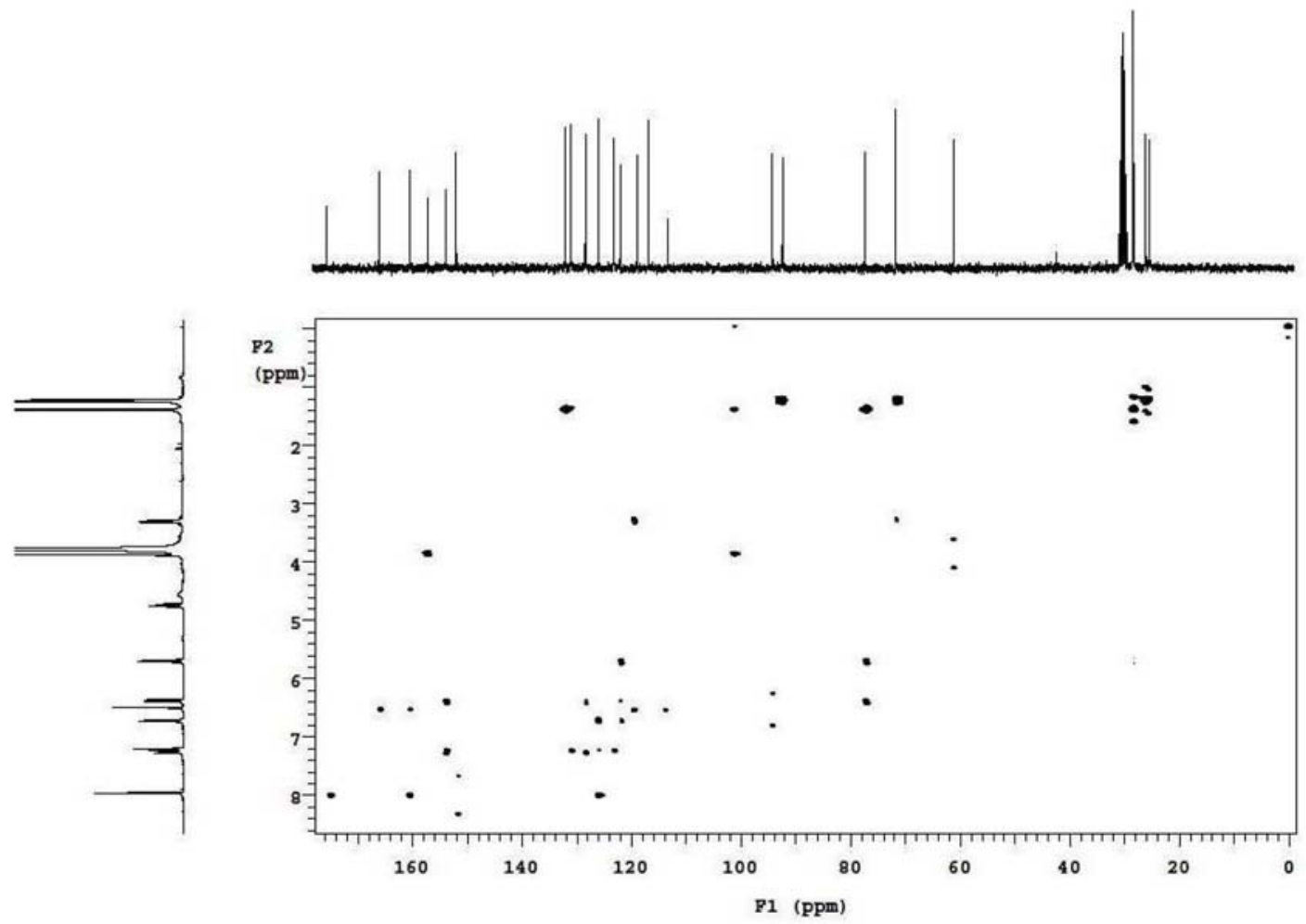

Figure 4S. HMBC spectrum $\left(300 / 75 \mathrm{MHz},\left(\mathrm{CD}_{3}\right)_{2} \mathrm{CO}\right)$ of coumpond 1

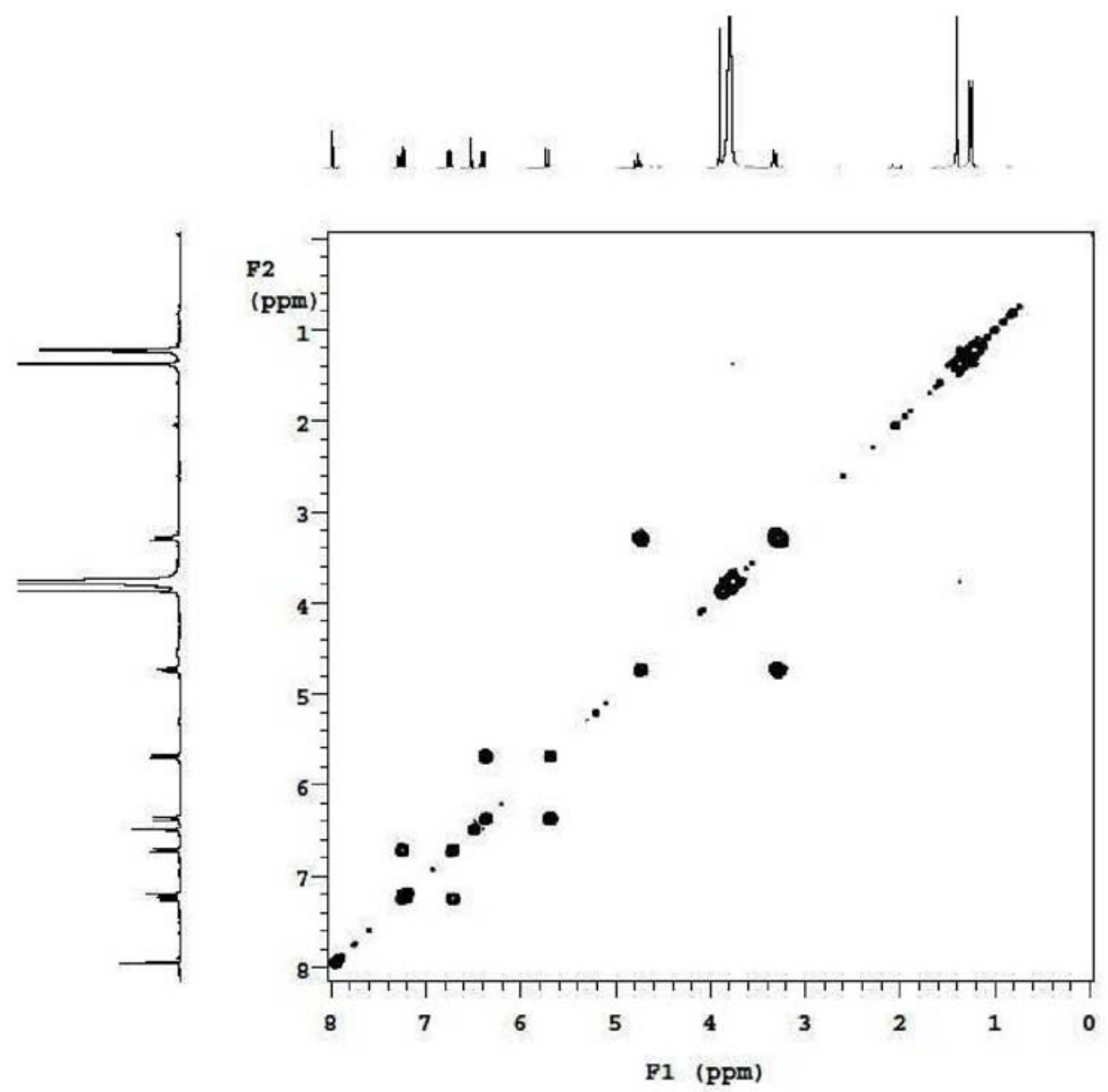

Figure 5S. COSY spectrum ( $\left.300 \mathrm{MHz}\left(\mathrm{CD}_{3}\right)_{2} \mathrm{CO}\right)$ of coumpond 1 
SH

Oyama et al.

Quit. Nova

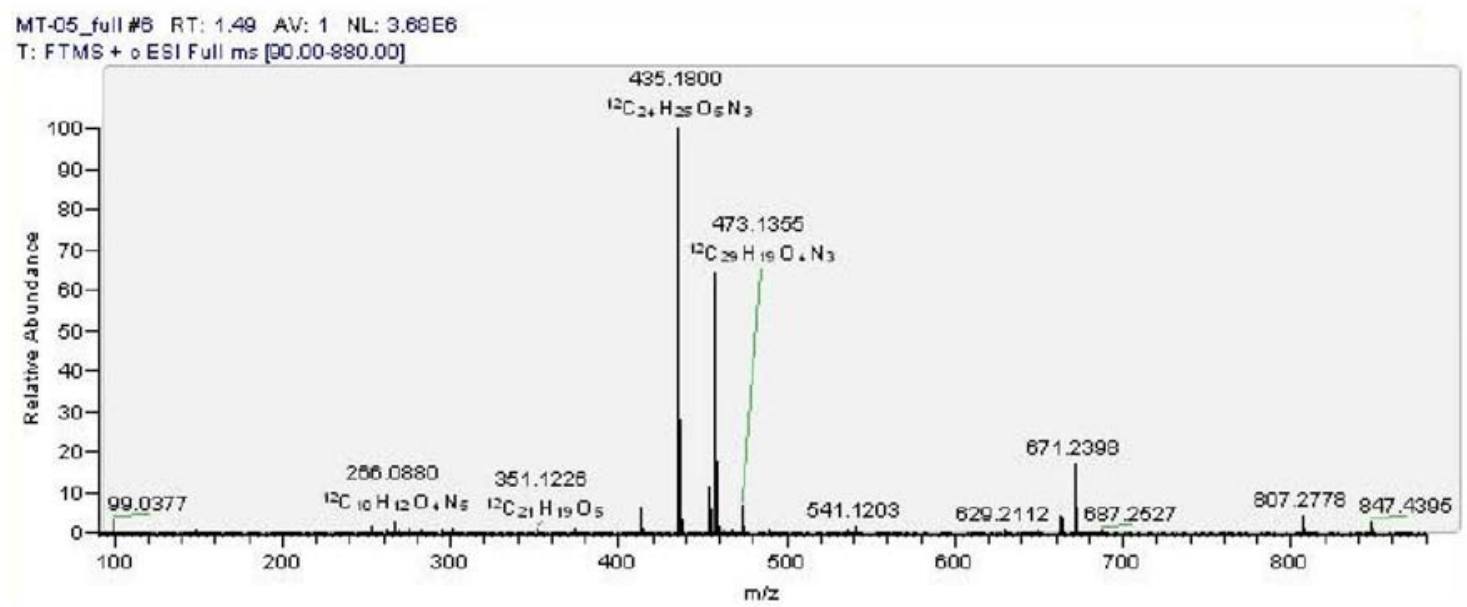

Figure 6S. HR-ESIMS positive mode of compound 1
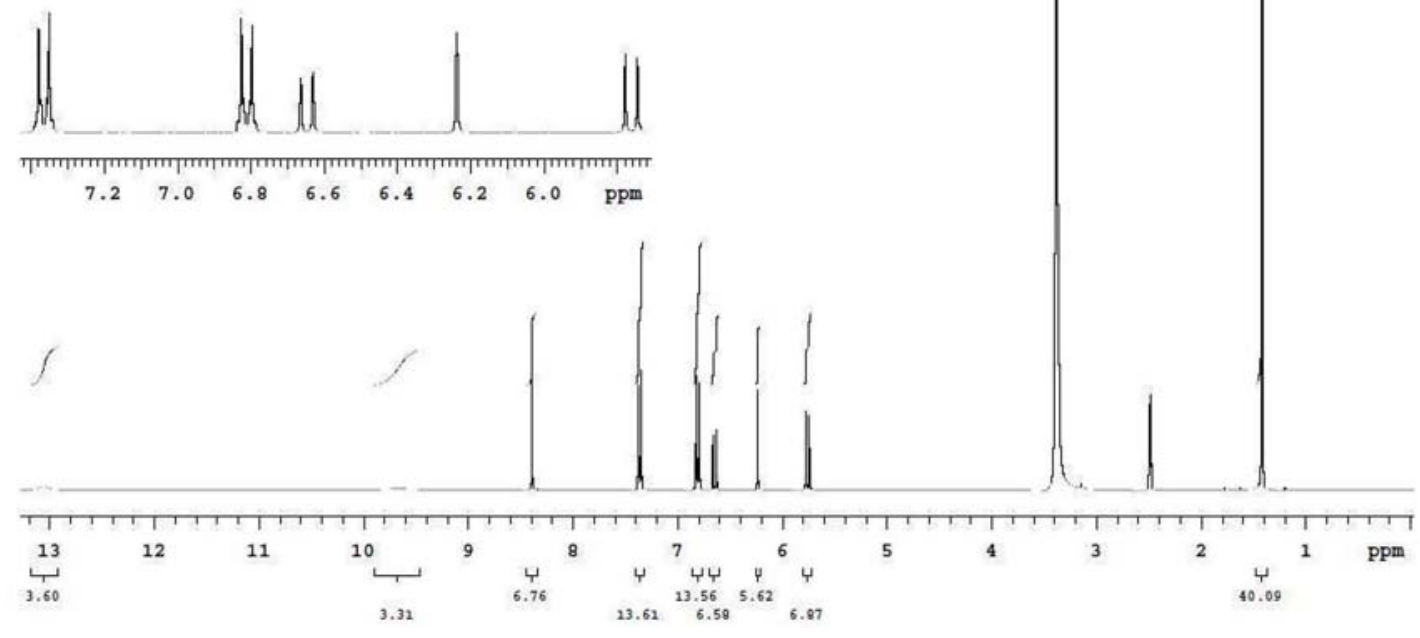

Figure $7 \mathrm{~S} .{ }^{1} \mathrm{H} N \mathrm{NR}$ spectrum $\left(300 \mathrm{MHz},\left(\mathrm{CD}_{3}\right)_{2} \mathrm{CO}\right)$ of coumpond 2 

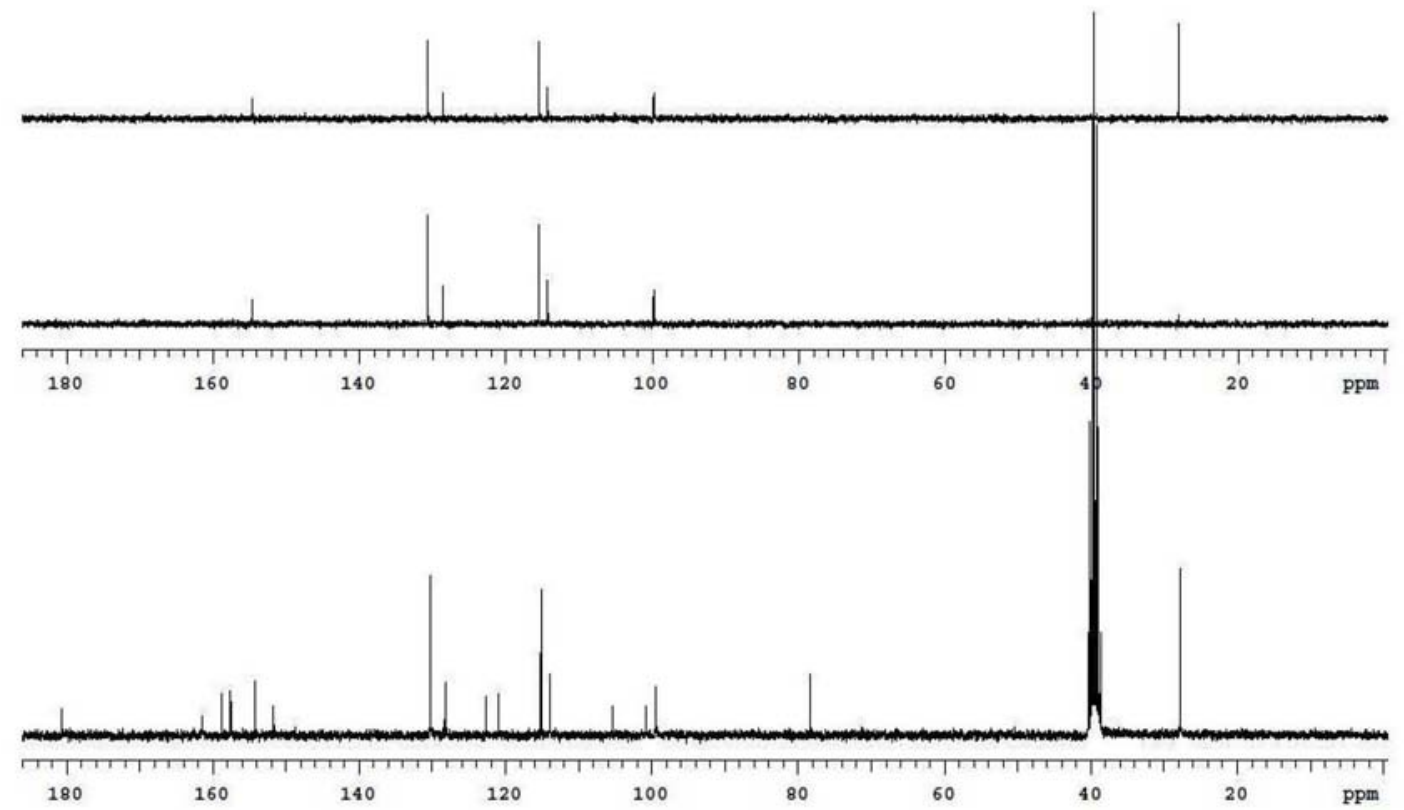

Figure 8S. ${ }^{13} \mathrm{C}$ and DEPT 90 spectrum $\left(75 \mathrm{MHz},\left(\mathrm{CD}_{3}\right)_{2} \mathrm{CO}\right)$ of coumpond 2

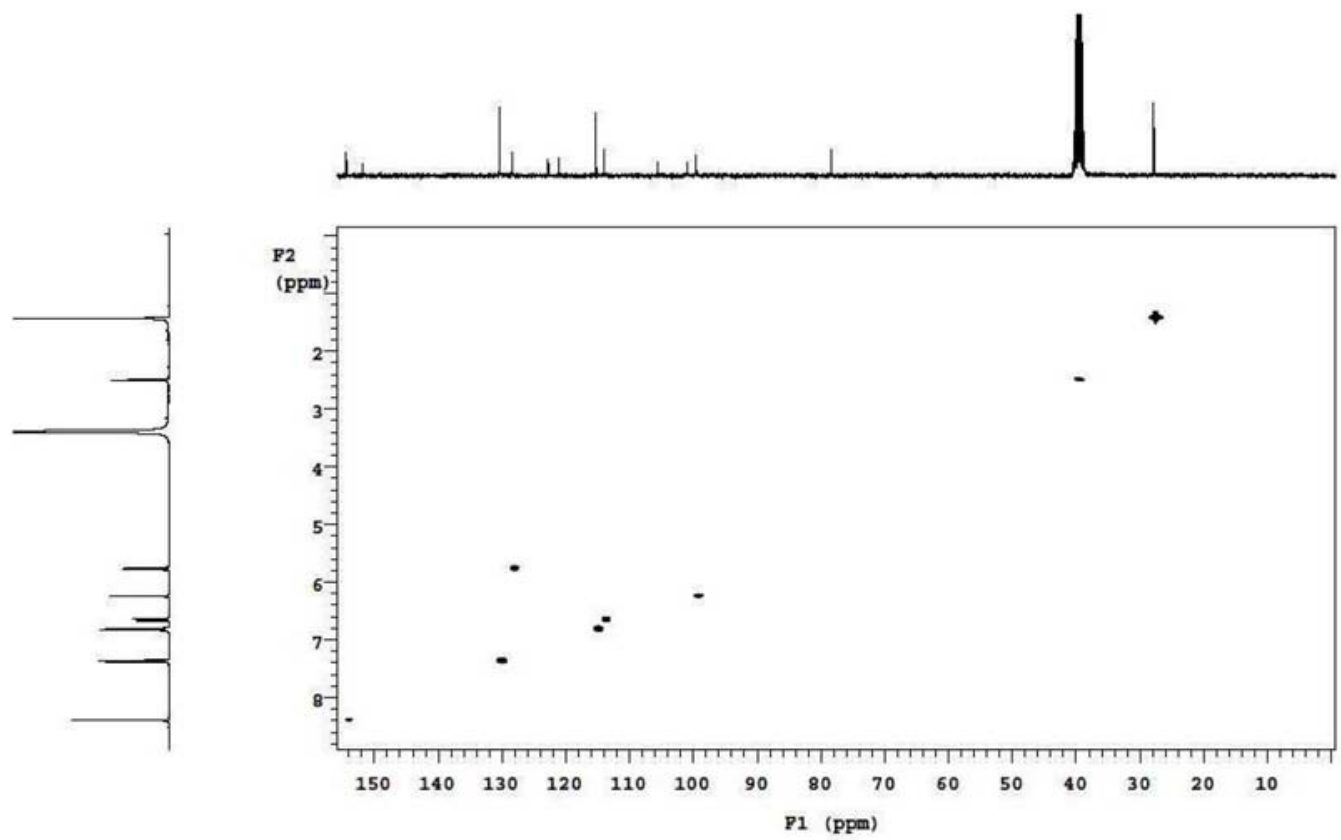

Figure 9S. HSQC spectrum $\left(300 / 75 \mathrm{MHz},\left(\mathrm{CD}_{3}\right)_{2} \mathrm{CO}\right)$ of coumpond 2 


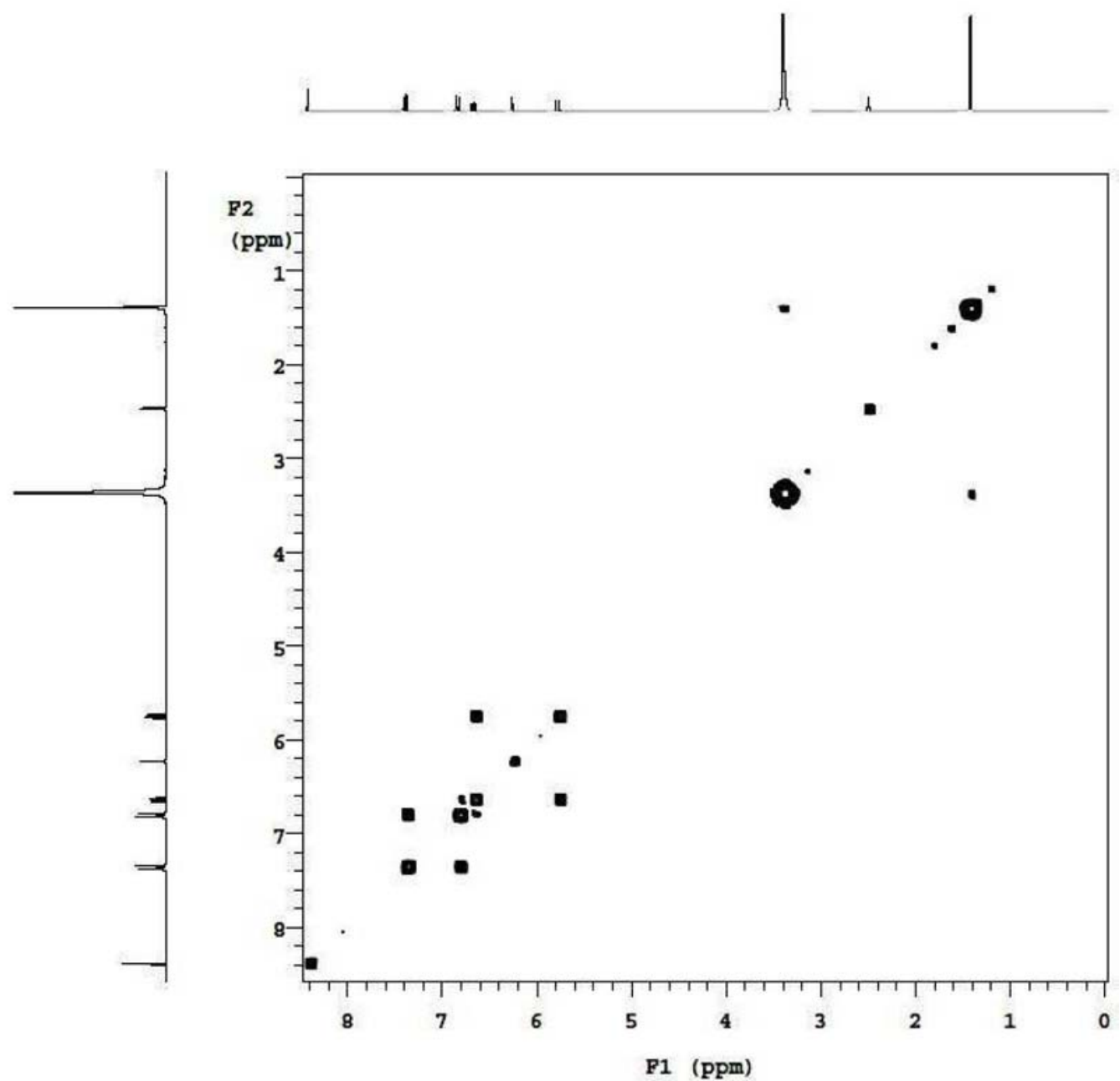

Figure 10S. COSY spectrum ( $\left.300 \mathrm{MHz}\left(\mathrm{CD}_{3}\right)_{2} \mathrm{CO}\right)$ of coumpond 2

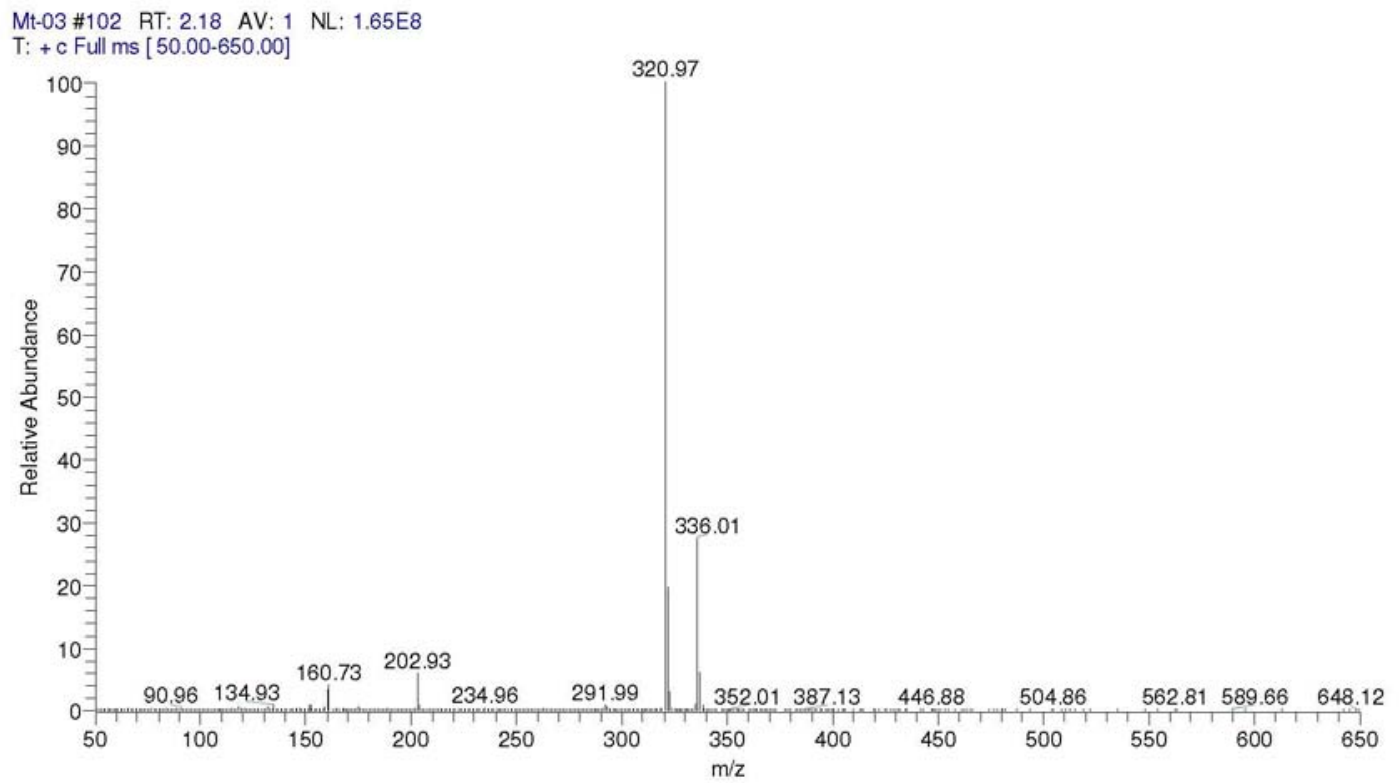

Figure 11S. EIMS $(70 \mathrm{eV})$ of compound 2 


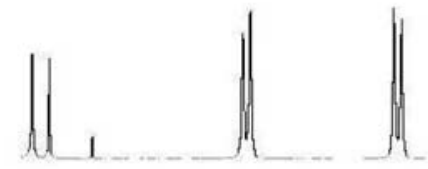

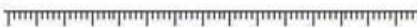
$\begin{array}{llllllll}8.2 & 8.0 & 7.8 & 7.6 & 7.4 & 7.2 & \mathrm{ppm}\end{array}$

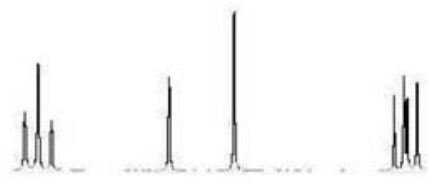

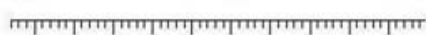
$\begin{array}{lllll}6.6 & 6.4 & 6.2 & 6.0 & \mathrm{ppm}\end{array}$

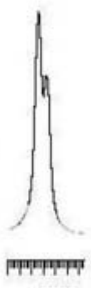

ppm

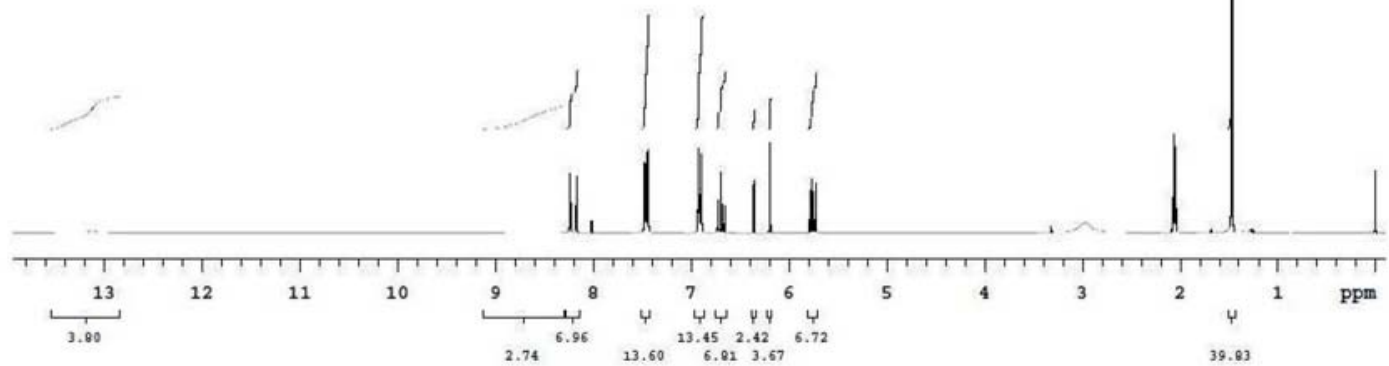

Figure 12S. ${ }^{1} \mathrm{H} \mathrm{NMR}$ spectrum $\left(300 \mathrm{MHz},\left(\mathrm{CD}_{3}\right)_{2} \mathrm{CO}\right)$ of coumpond 3

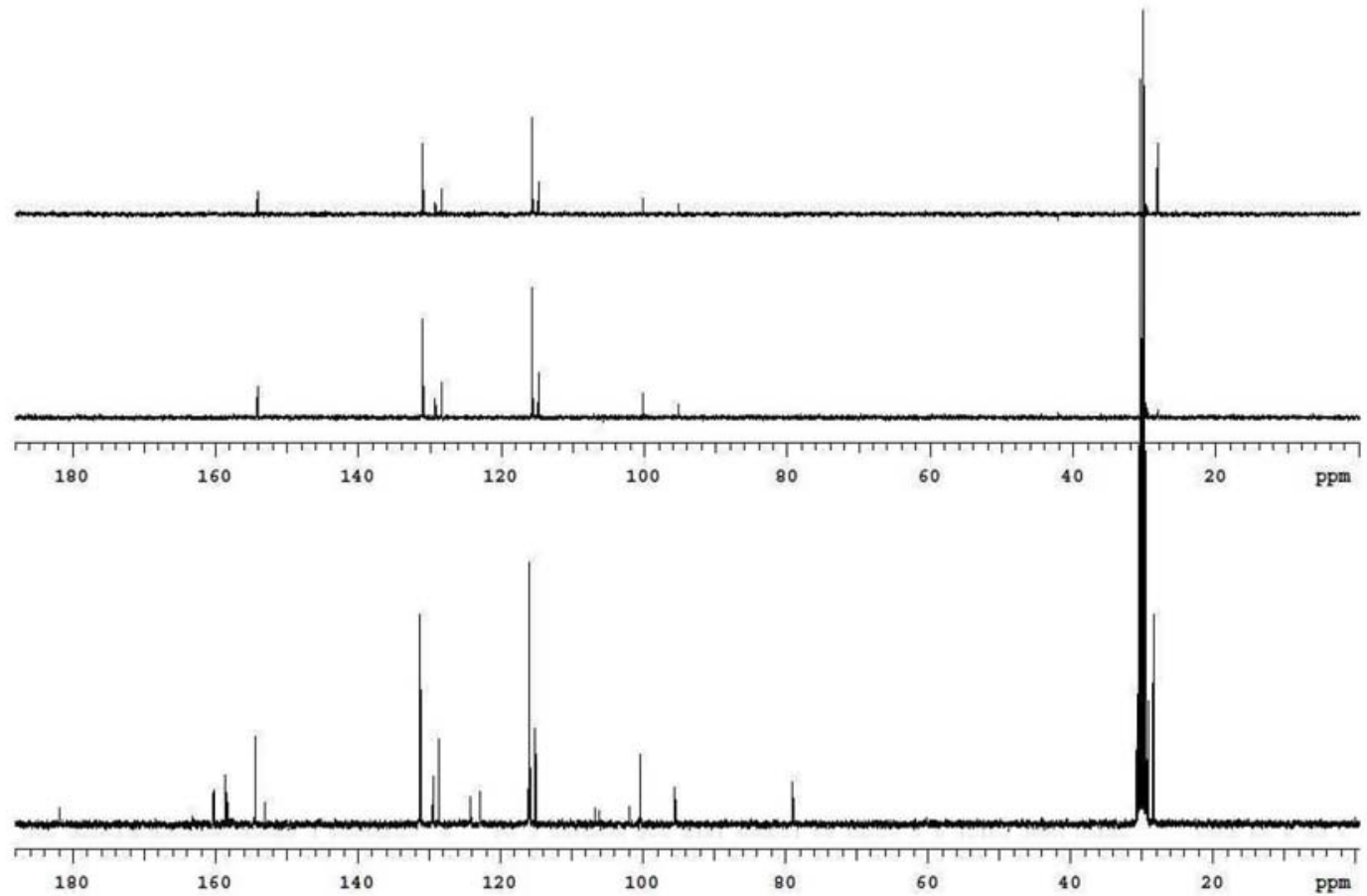

Figure 13S. ${ }^{13} \mathrm{C}$ and DEPT 90 spectrum $\left(75 \mathrm{MHz},\left(\mathrm{CD}_{3}\right)_{2} \mathrm{CO}\right)$ of coumpond 3 


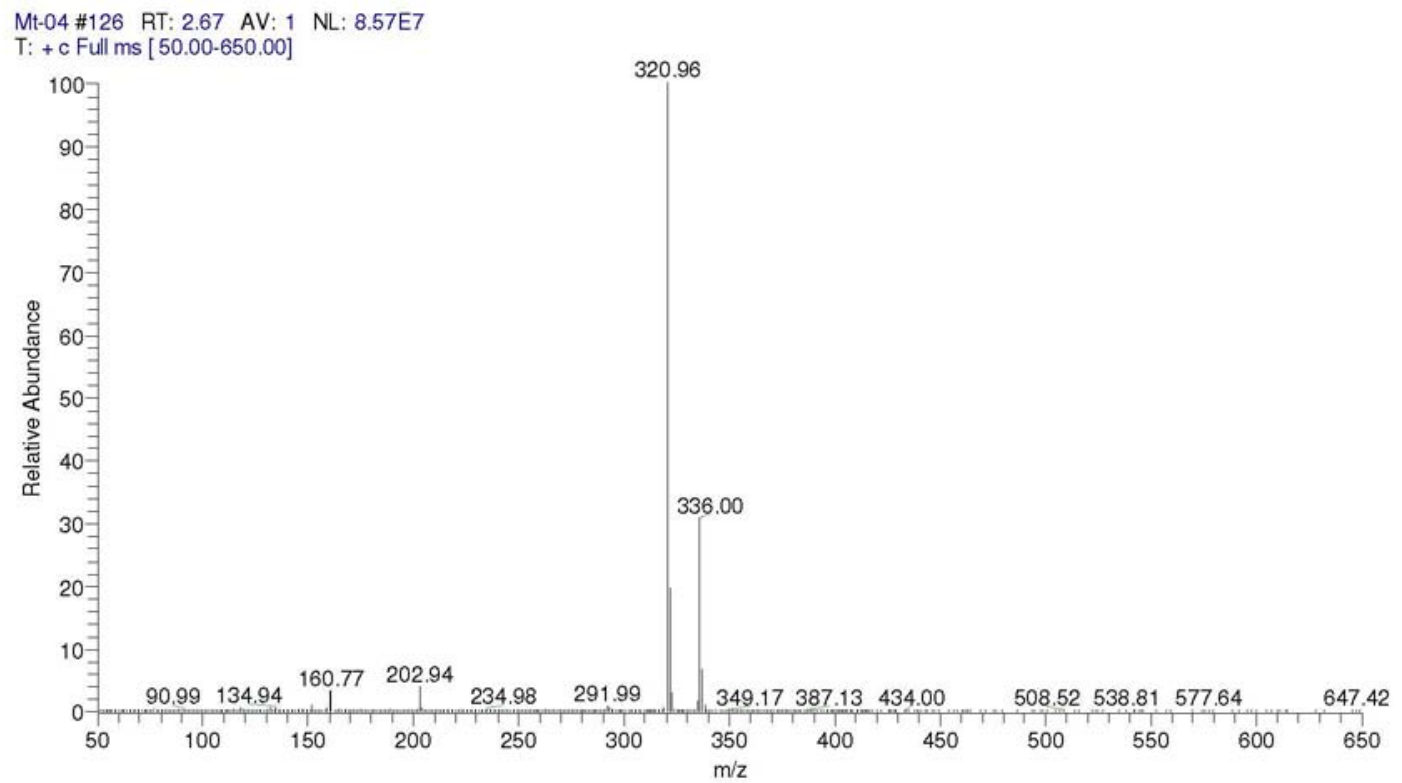

Figure 14S. EIMS $(70 \mathrm{eV})$ of compound 3

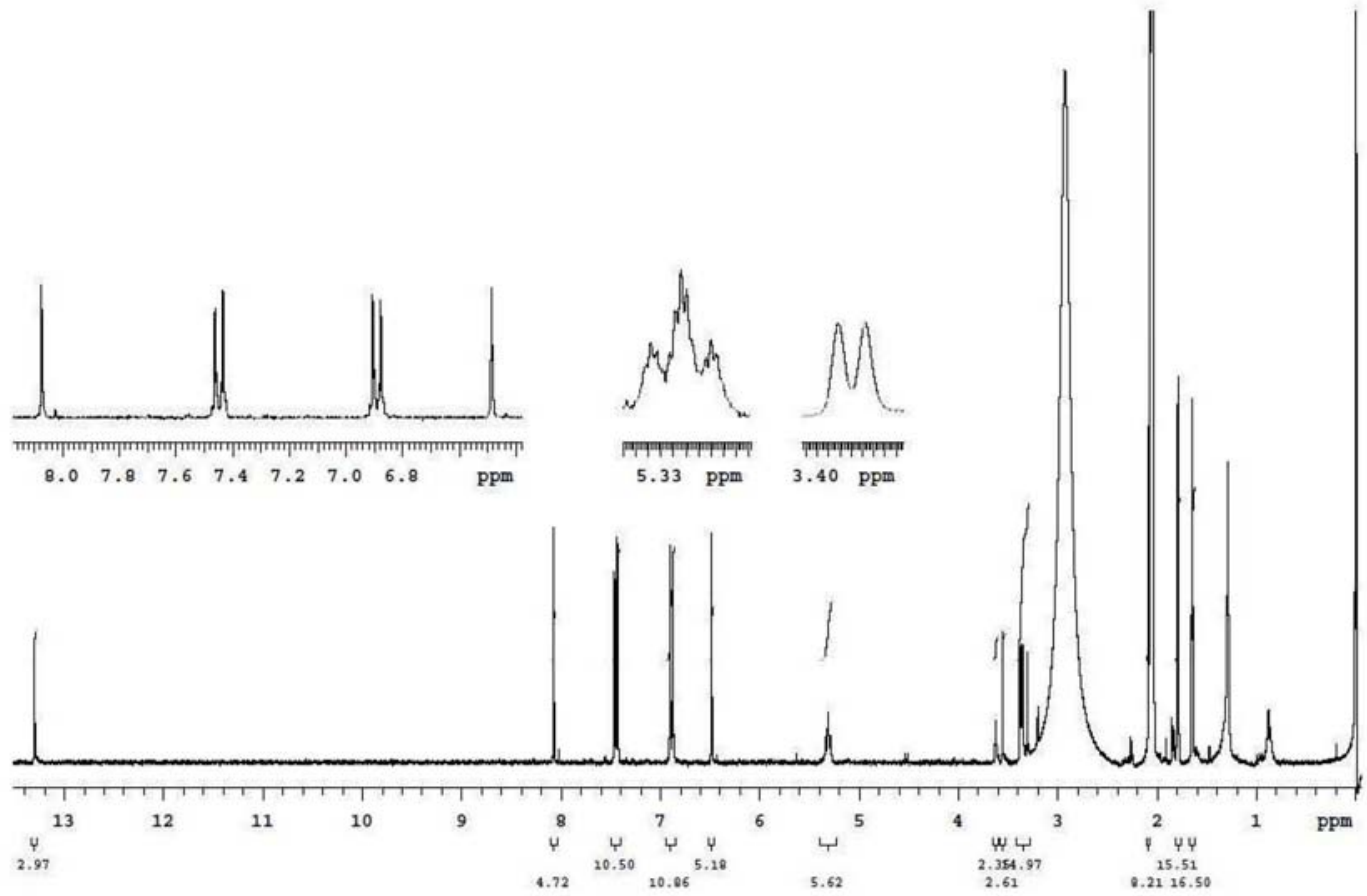

Figure 15S. ${ }^{1} \mathrm{H}$ NMR spectrum $\left(300 \mathrm{MHz},\left(\mathrm{CD}_{3}\right)_{2} \mathrm{CO}\right)$ of coumpond 4 


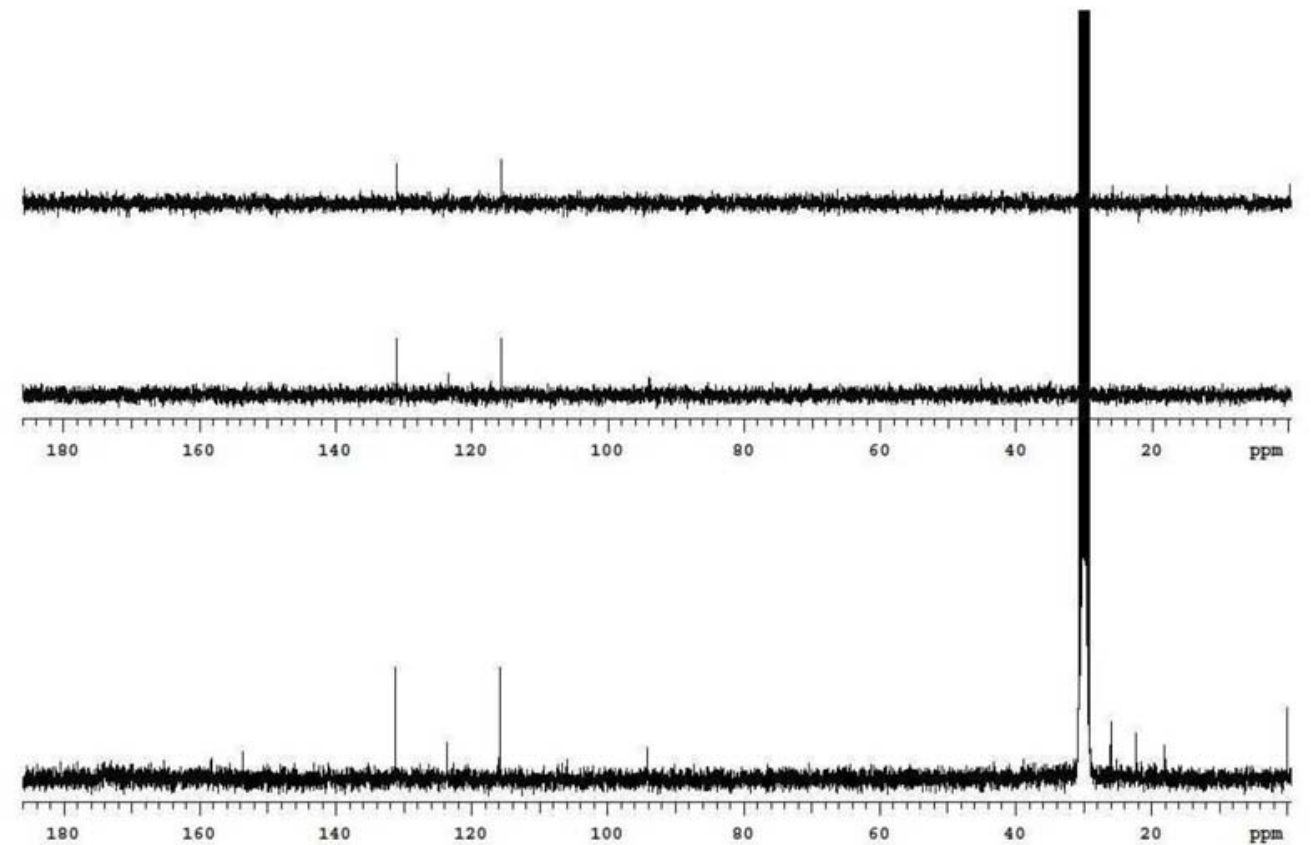

Figure 16S. ${ }^{13} \mathrm{C}$ and DEPT 90 spectrum $\left(75 \mathrm{MHz},\left(\mathrm{CD}_{3}\right)_{2} \mathrm{CO}\right)$ of coumpond 4

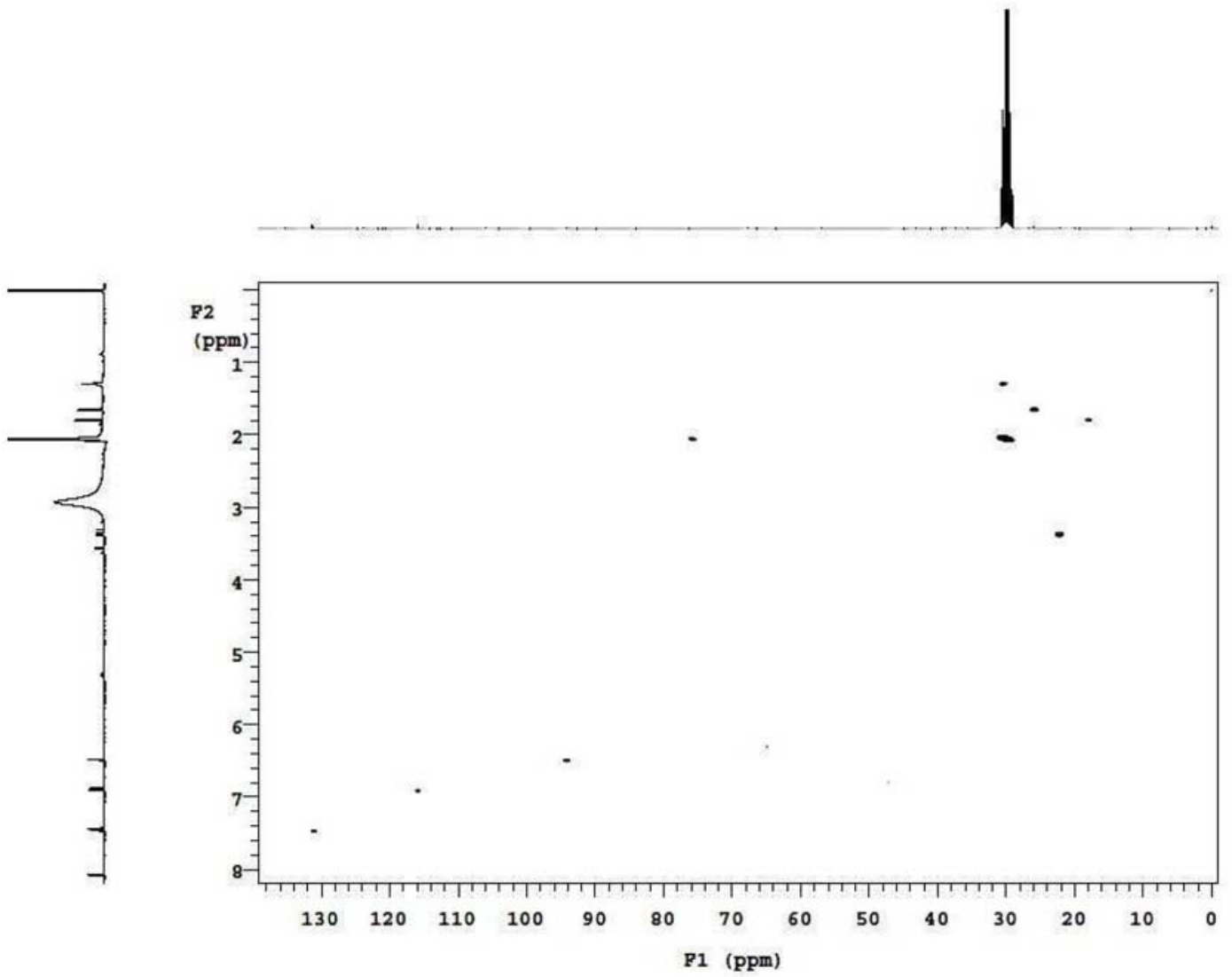

Figure 17S. HSQC spectrum (300/75 $\left.\mathrm{MHz},\left(\mathrm{CD}_{3}\right)_{2} \mathrm{CO}\right)$ of coumpond 4 


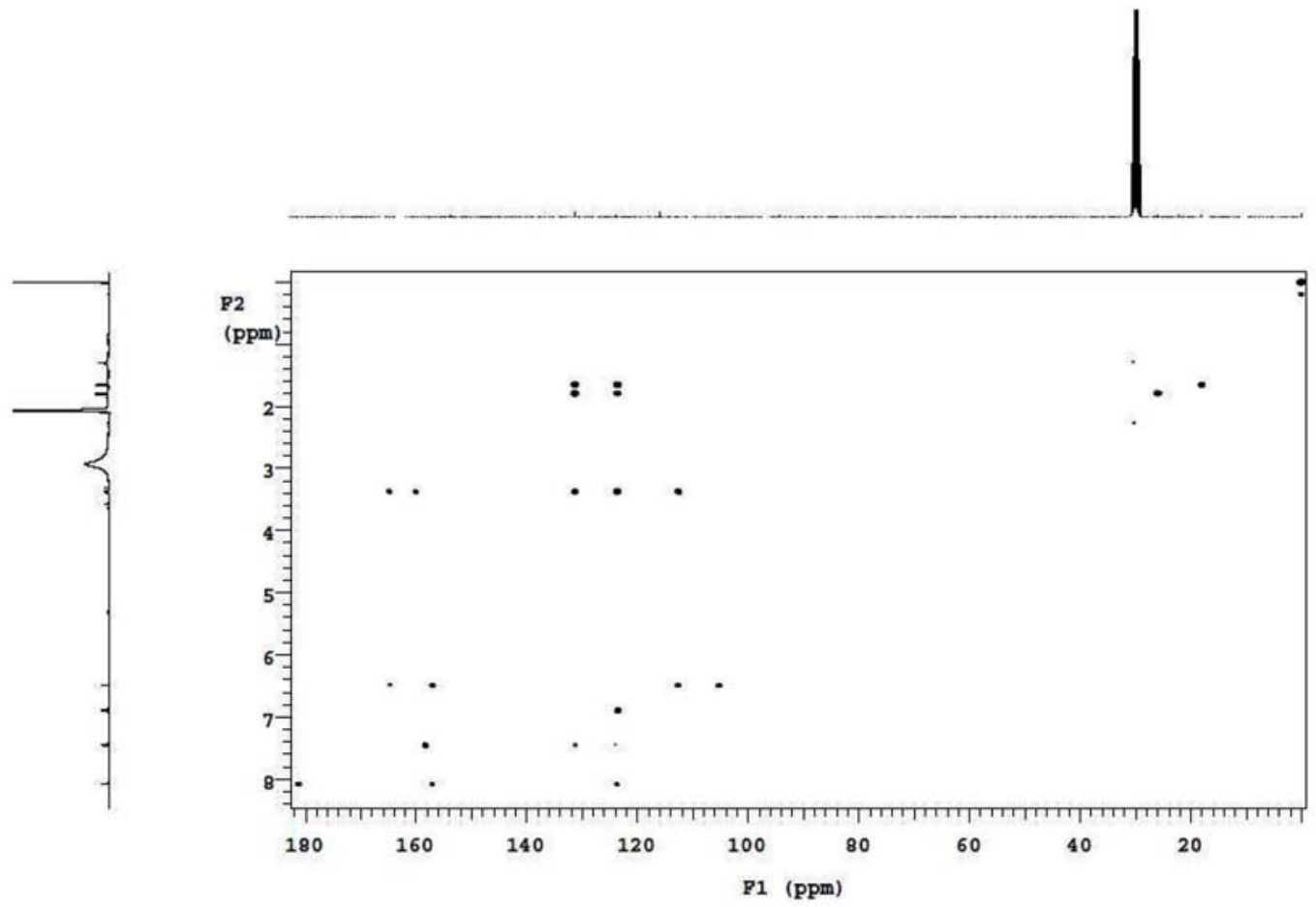

Figure 18S. HMBC spectrum (300/75 $\left.\mathrm{MHz},\left(\mathrm{CD}_{3}\right)_{2} \mathrm{CO}\right)$ of coumpond 4
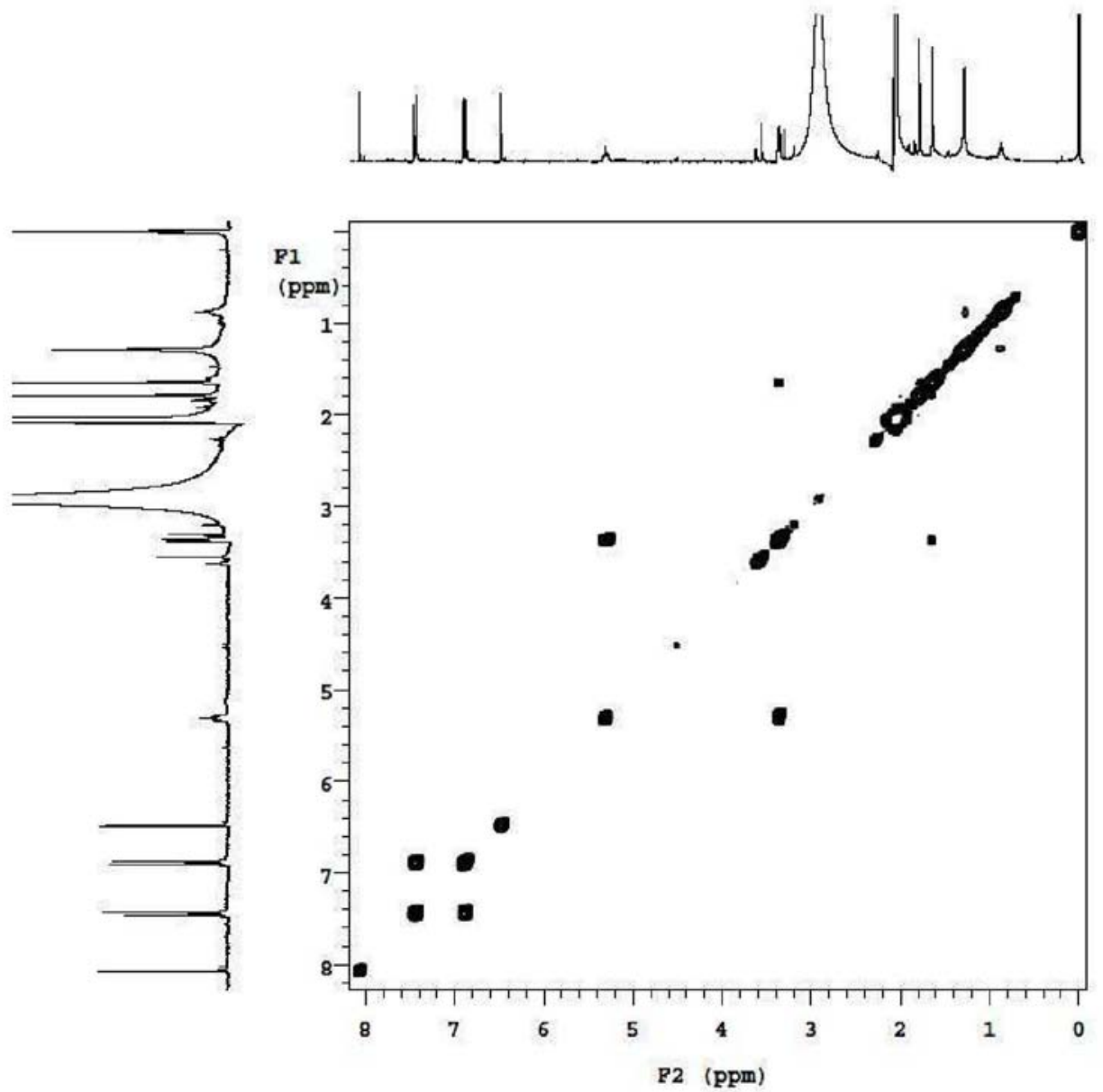

Figure 19S. COSY spectrum (300 $\left.\mathrm{MHz}\left(\mathrm{CD}_{3}\right)_{2} \mathrm{CO}\right)$ of coumpond 4 


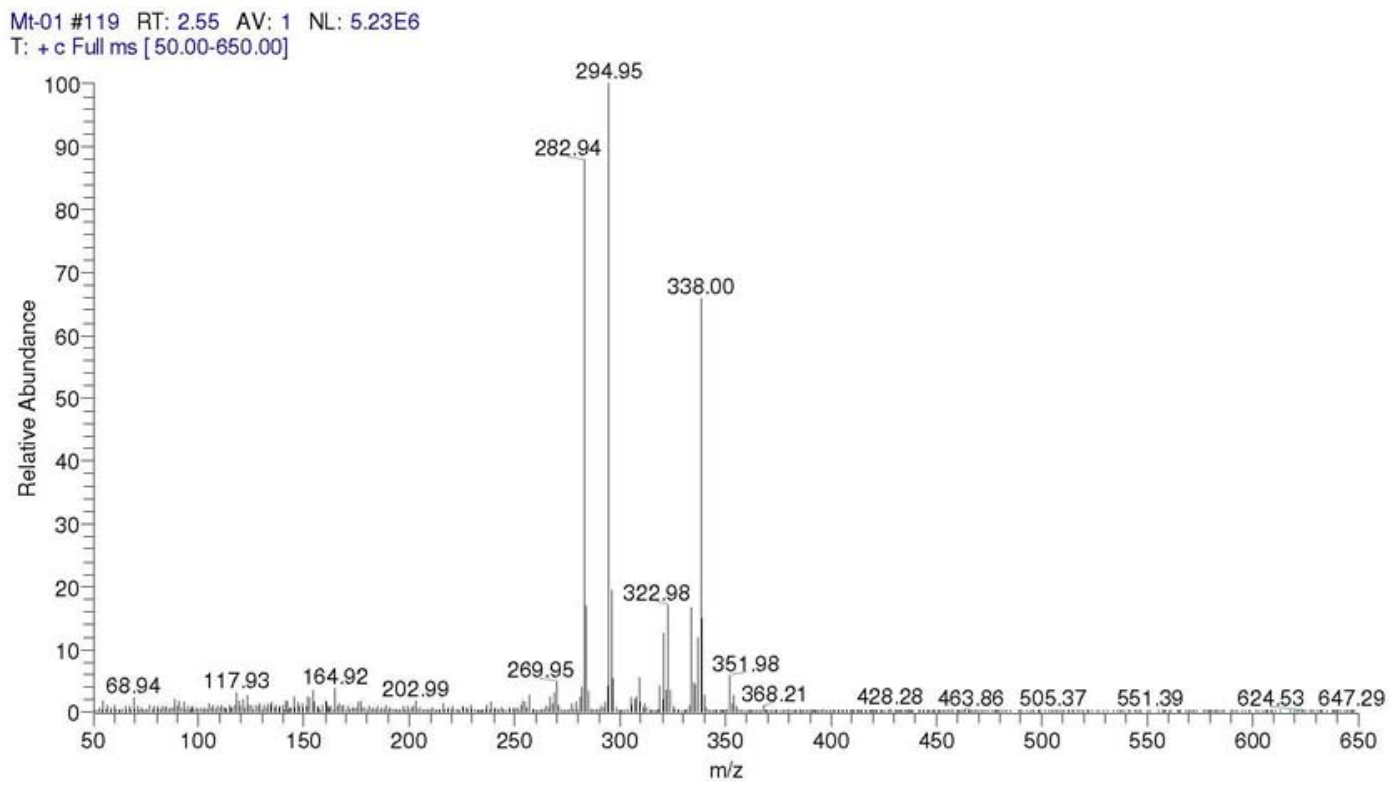

Figure 20S. EIMS (70 eV) of compound 4

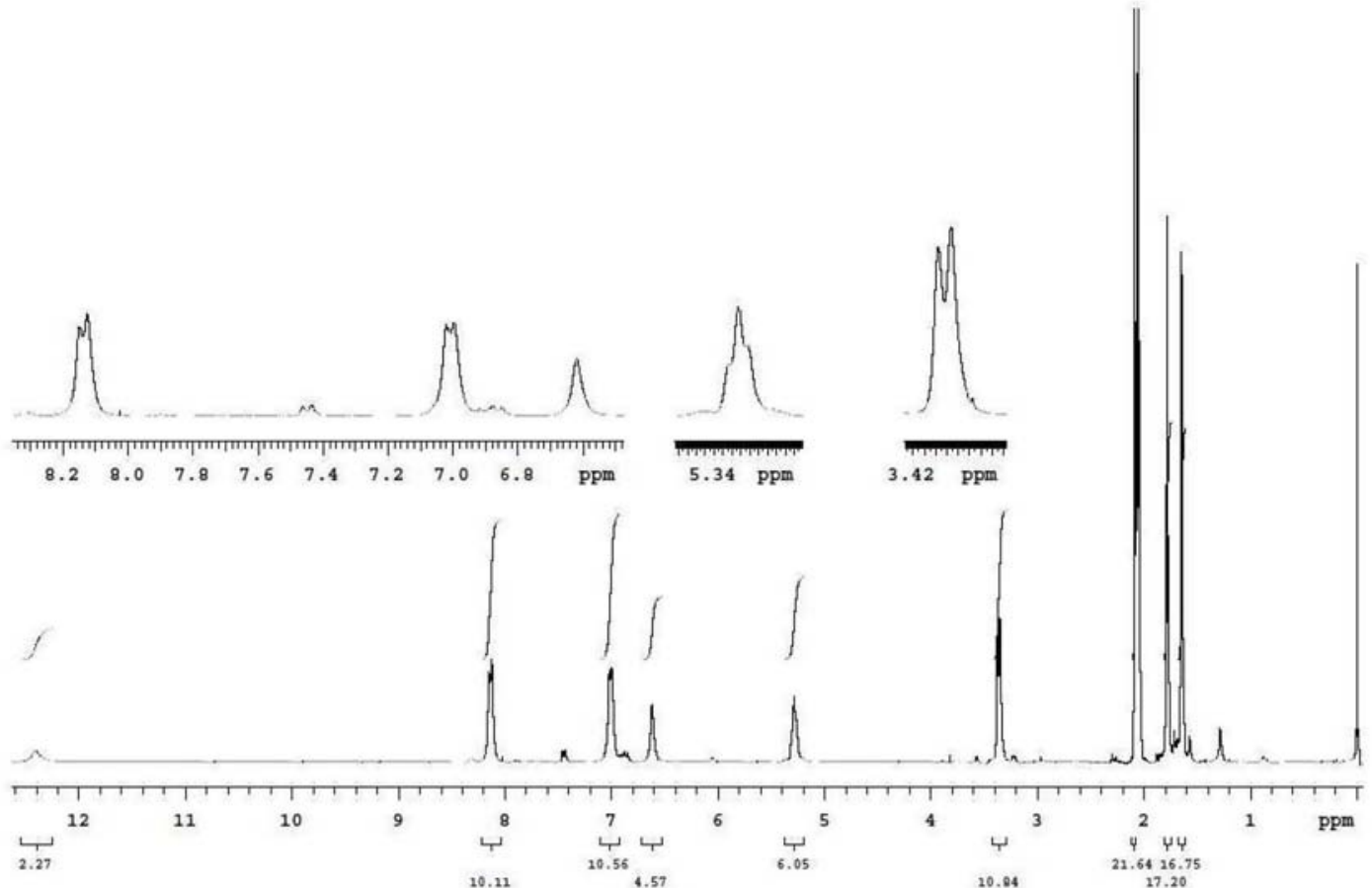

Figure 21S. ${ }^{1} \mathrm{H}$ NMR spectrum $\left(300 \mathrm{MHz},\left(\mathrm{CD}_{3}\right)_{2} \mathrm{CO}\right)$ of coumpond 5 


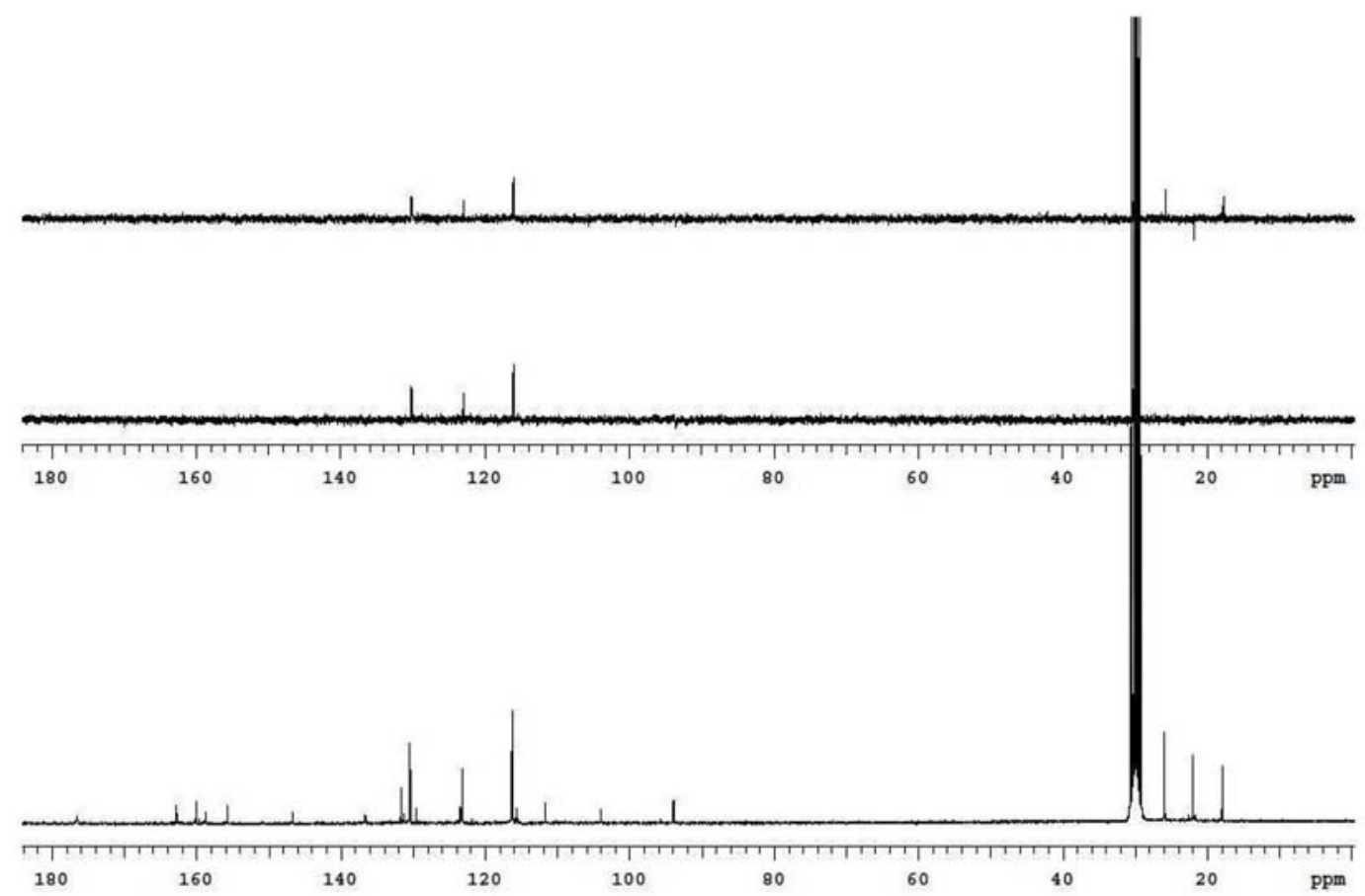

Figure 22S. ${ }^{13} \mathrm{C}$ and DEPT 90 spectrum $\left(75 \mathrm{MHz},\left(\mathrm{CD}_{3}\right)_{2} \mathrm{CO}\right)$ of coumpond 5

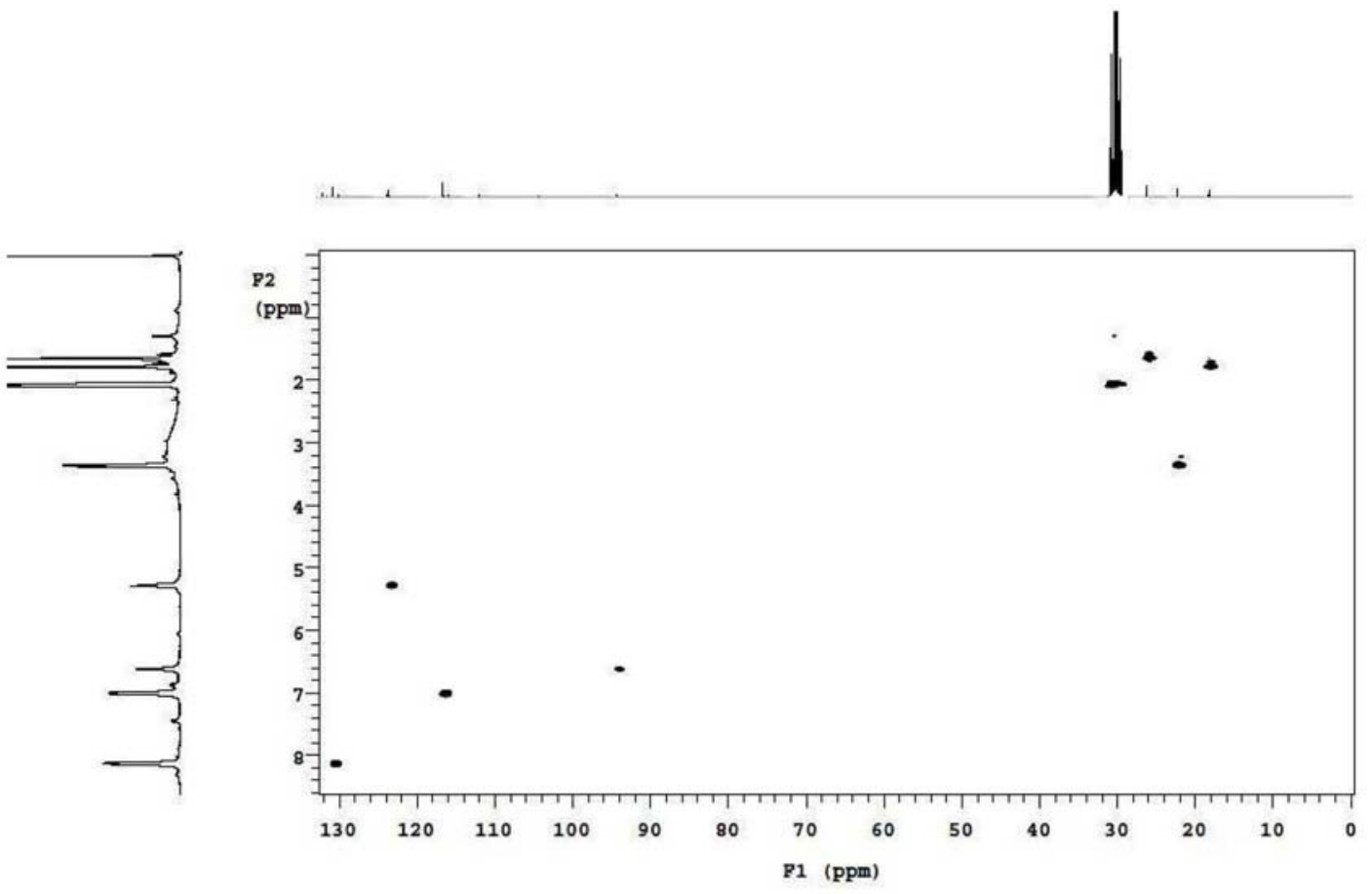

Figure 23S. HSQC spectrum (300/75 $\left.\mathrm{MHz},\left(\mathrm{CD}_{3}\right)_{2} \mathrm{CO}\right)$ of coumpond 5 


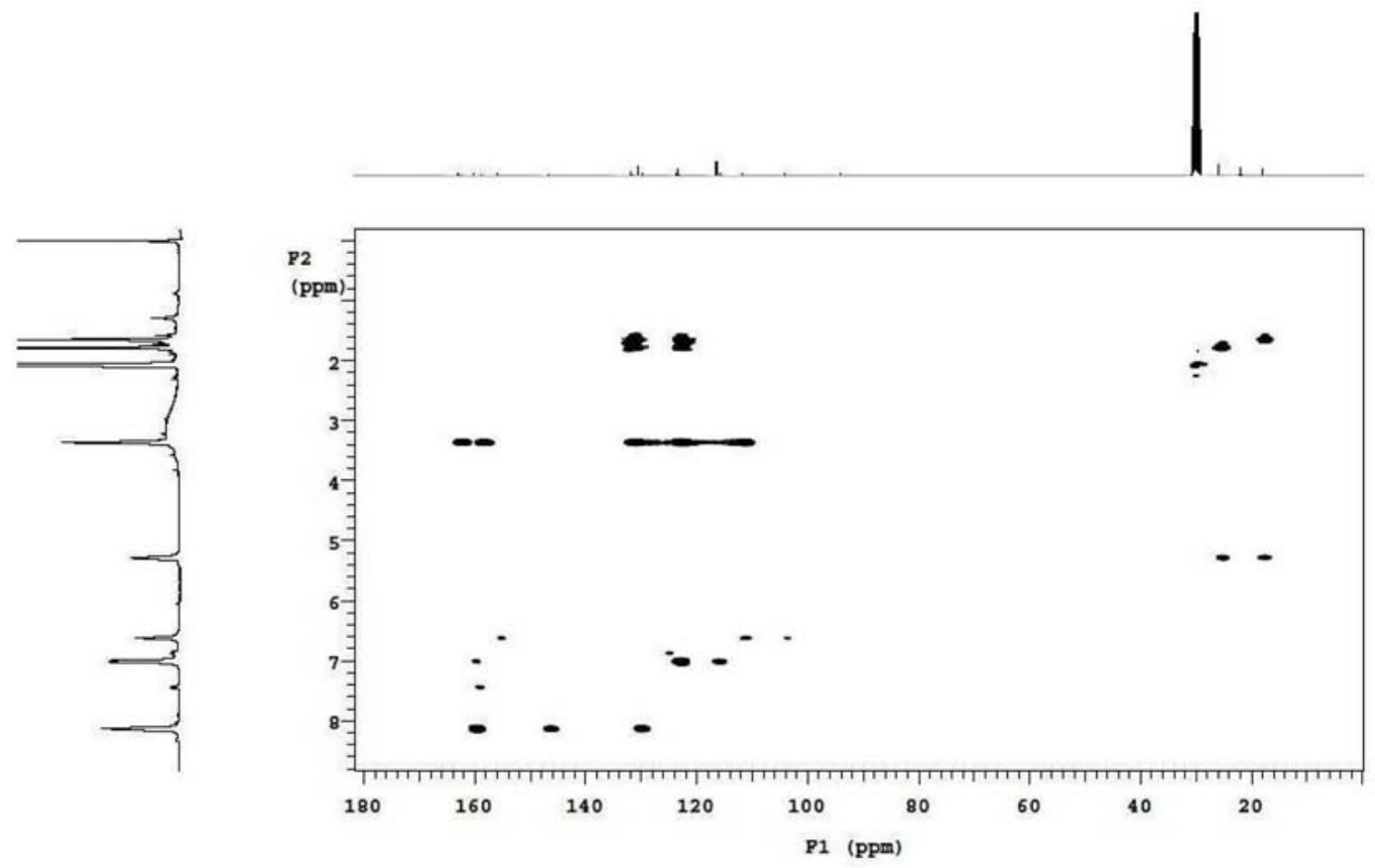

Figure 24S. HMBC spectrum $\left(300 / 75 \mathrm{MHz},\left(\mathrm{CD}_{3}\right)_{2} \mathrm{CO}\right)$ of coumpond 5

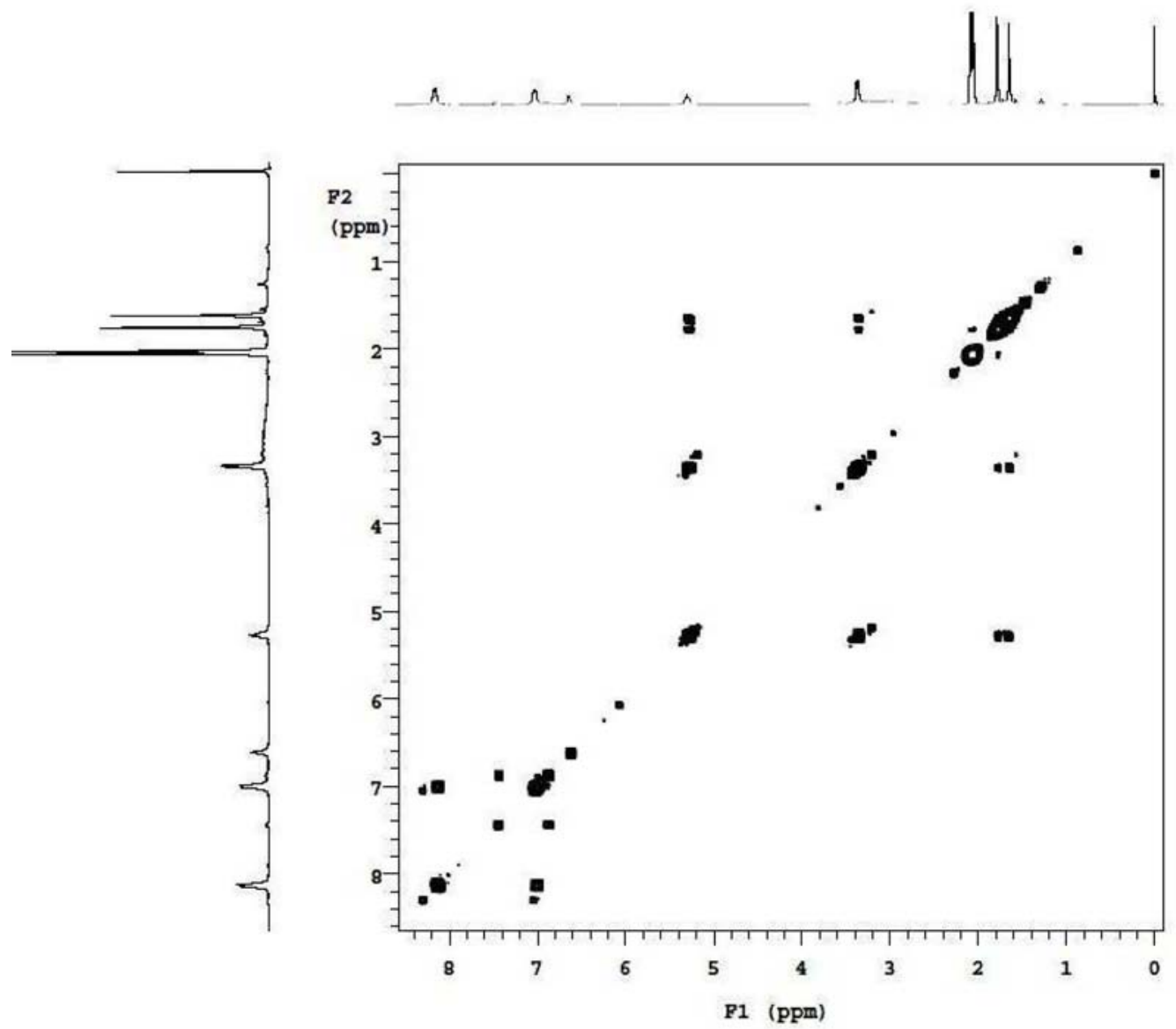

Figure 25S. COSY spectrum $\left(300 \mathrm{MHz}\left(\mathrm{CD}_{3}\right)_{2} \mathrm{CO}\right)$ of coumpond 5 


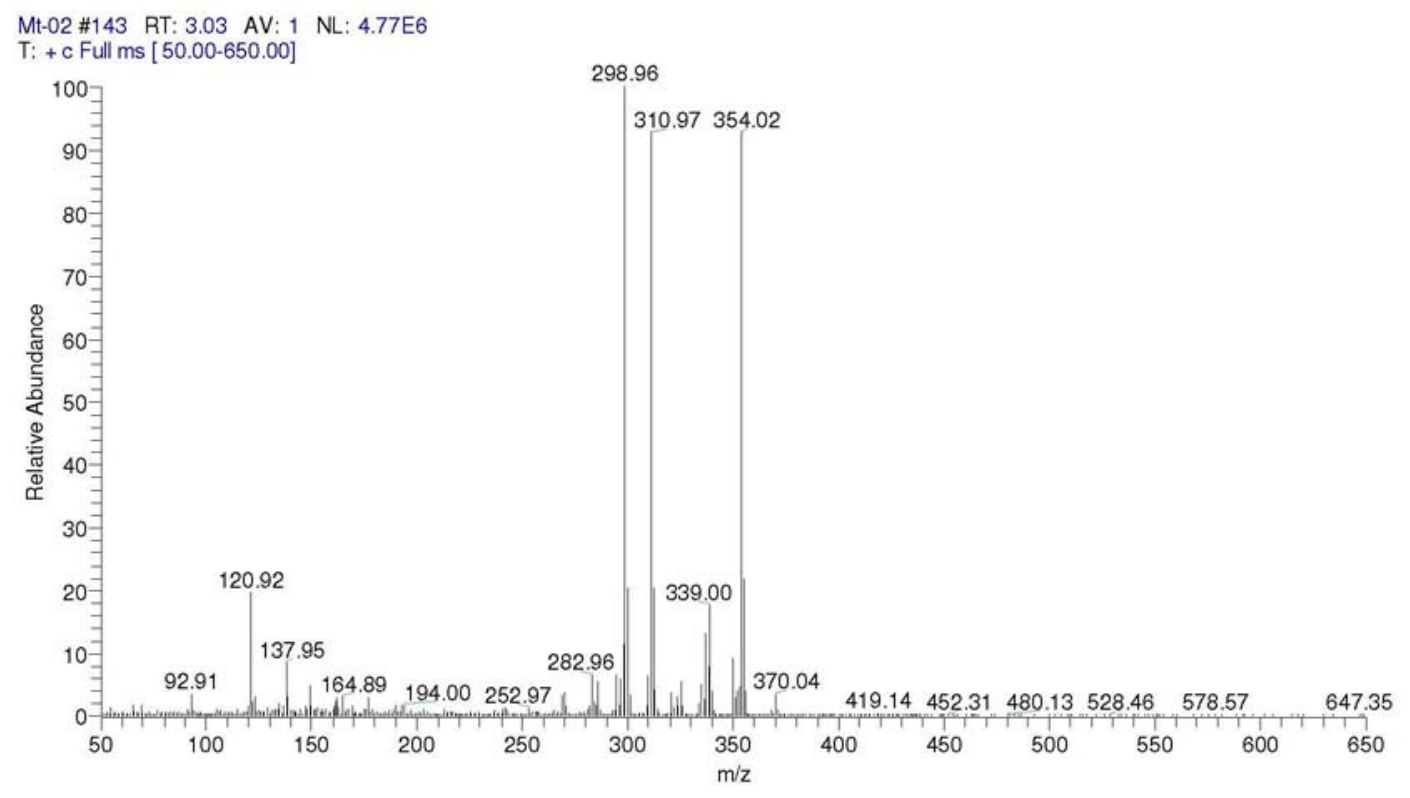

Figure 26S. EIMS (70 eV) of compound 5 